Part of Journal of Research of the National Bureau of Standards, Volume 16, May 1936

\title{
SOIL-CORROSION STUDIES, 1934. RATES OF LOSS OF WEIGHT AND PITTING OF FERROUS SPECIMENS
}

\author{
By K. H. Logan
}

ABSTRACT

The soil-corrosion investigation which was started in 1922 was originally planned to cover 12 years, plus the time required to write the final report. In 1934 the last of the original specimens were removed from 23 soils, but additions to the original test have so altered the plans that there now remain in the ground 7,500 specimens buried by the National Bureau of Standards and approximately 2,000 specimens of protective coatings prepared by research associates.

In general, the results of the examination of the specimens removed in 1934 confirm earlier conclusions. The additional data permit the calculation of the standard errors for certain classes of data.

The average maximum penetrations for the wrought-iron, Bessemer, and open-hearth specimens do not differ by more than a few percent. The specimens of open-hearth iron and of open-hearth steel containing 0.2 percent of copper appear to pit slightly more deeply than the other wrought specimens. In some soils cast iron corrodes somewhat more rapidly than steel.

Soils differ so greatly in corrosiveness that the average rates of corrosion or the average life of a pipe have little practical value.

The addition of chromium to steel reduces the loss of weight by corrosion and the number of pits, but even a large percentage of chromium will not prevent serious pitting. This is especially true with respect to soils containing chlorides. The addition of nickel, with or without chromium, tends to reduce the depth of the pits.

Certain materials seem to be especially suited or unsuited to certain types of soils.

\section{CONTENTS}

I. Introduction

II. Presentation and discussion of the data on 12-year-old specimens..- 436

1. Rates of loss of weight _..... 436

2. Rates of penetration by pitting 438

3. Pitting factors

III. Significance of the data

1. Application of the data to pipe lines

2. Relative merits of materials

3. Corrosiveness of soils . .

IV. Special materials and tests

1. Supplementary tests of pipes in corrosive soils.

2. Bolts

3. High-silicon cast iron

4. Influence of mill and foundry scale...

5. Effect of area and diameter of specimens on the rate of penetration

$\mathrm{V}$. Tests of materials in corrosive soils

1. Tubes containing 26 percent of chromium

2. Pipe buried in 1932

VI. Summary _... 


\section{INTRODUCTION}

In 1922 the National Bureau of Standards undertook to determine the corrosiveness of 46 soils selected for the most part by the U. S. Department of Agriculture as representative of the soils in various parts of the country which contained extensive installations of pipes. This determination was to be accomplished through the examination at 2-year intervals of 1 of 6 sets of the commonly used ferrous pipe

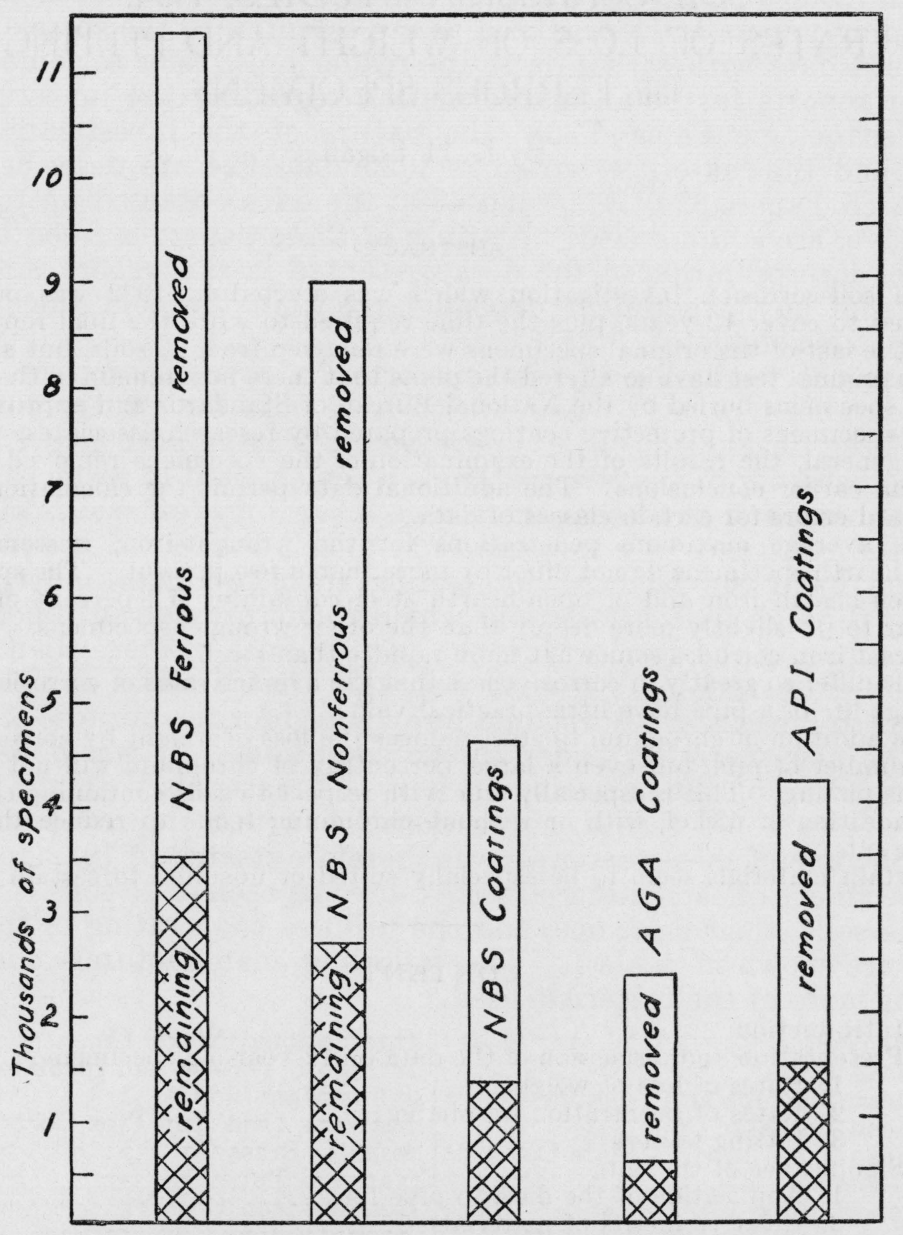

FIGURE 1.-Status of the soil-corrosion investigation.

materials. From time to time progress reports on this work have been issued. It was expected that at the close of the investigation all of the essential data and conclusions would be assembled in a single final report.

In 1934 the sixth and last set of the original specimens was removed from 23 soils, and this report presents the data on these specimens as well as on specimens from 39 other test sites. These sites include all the 12-year-old specimens. It is not advisable, however, to issue a final comprehensive report on the soil-corrosion investigation at this time because the investigation has been extended from time to 
time by the burial of specimens of other materials and because specimens of the original materials bave been left in the less corrosive soils. The status of the field investigation as of January 1, 1936, is shown in figure 1.

This report like previous ones on this investigation is a progress report, although an attempt is made to state more definitely the significance of that part of the investigation which has been completed. Since only 1934 data are tabulated, and only such parts of preceding papers are reproduced as are essential to the correlation of the 1934 data with earlier data, the reader must refer to some of the earlier reports for detailed information regarding the investigation. In Technologic Paper T368 ${ }^{1}$ the nature of the investigation, the soils, and the materials buried in 1922 and 1924 are described. In Research Papers $329,{ }^{2} 359,{ }^{3}$ and $638^{4}$ the data obtained up to 1932 , inclusive, are summarized. A study of these papers is essential to a correct interpretation of the data presented in tbis report, since the results of any experiment depend largely on the conditions under which it is conducted.

Since the beginning of the soil-corrosion investigation in 1922 a considerable number of new varieties of pipe for underground use have been developed. These developments have been based largely on the behavior of the new materials when exposed to water or to the atmosphere, and at present there is no laboratory test which will indicate the resistance of a new material to soil action. Since few pipe makers have the facilities for testing their products underground, except through trial installations which do not provide an opportunity for comparing the results with the performance of more than one or two other materials, it seemed desirable that a series of field tests similar to the earlier tests should be arranged for the purpose of trying out the new materials under known conditions. It was hoped that a correlation of the characteristics of the materials with the results of the tests would furnish suggestions for further improvements. A test of some of these materials was therefore started in 1932, in which 10 specimens of each material were buried in each of 15 soils.

The soils, their locations, and the utilities cooperating in the 1932 tests are shown in table 1. The following manufacturers furnished one or more of the materials used.
Allegheny Steel Co.
American Brass Co.
American Machine and Foundry Co.
American Radiator Co.
American Sheet and Tin Plate Co.
Ball Chemical Co.
Bridgeport Brass Co.
Cast Iron Pipe Research Association.
Chadeloid Chemical Co.
Chase Brass and Copper Co.
Electro Metallurgical Co.
Ferro Enamel Corporation.
P. D. George Co.
Goodyear Tire and Rubber Co.
Harpoon Paint Products, Inc.

International Nickel Co.

Irvington Varnish and Insulator Co.

Johns-Manville Co.

McWane Cast Iron Pipe Co.

Mueller Brass Co.

National Tube Co.

Reading Iron Co.

Republic Steel Corporation.

Revere Copper and Brass Inc.

Ross-Meehan Foundries.

Scovill Manufacturing Co.

Sharon Steel Hoop Co.

Thiokol Corporation.

Walworth Alabama Co.

1 K. H. Logan, S. P. Ewing, and C. D. Yeomans, Bureau of Standards soil-corrosion studies: I. Soils, materials, and results of early observations. Tech. Pap. BS 22, 447 (1928). T368, $50 \phi$.

$2 \mathrm{~K}$. H. Logan and V. A. Grodsky, Soil-corrosion studies, 1930 . Rates of corrosion and pitting of bare ferrous specimens. BS J. Research 7, 1 (1931) RP329, 10ф.

K. H. Logan, Soil corrosion studies: Nonferrous metals and alloys, metallic coatings and specially prepared ferrous pipes removed in 1930 . BS J. Research 7, 585 (1831). RP359, $10 \mathrm{c}$.

4 K. H. Logan and R. H. Taylor, Soil-corrosion studies, 19s2. Rates of loss of weight and pitting of ferrous and nonferrous specimens removed in 1982 and metallic protective coatings. BS J. Research 12,119 (1934) RP638, 5t. 
TABLE 1.-Soils, test sites, and cooperating utilities in the 1932 tests

\begin{tabular}{|c|c|c|c|}
\hline Soil & Name of soil & Approximate location & Cooperator \\
\hline $\begin{array}{l}51 \\
52 \mathrm{a} \\
53 \\
54 \mathrm{a} \\
55\end{array}$ & $\begin{array}{l}\text { Acadia clay } \\
\text { Alkali knoll } \\
\text { Cecil clay loam } \\
\text { Fairmount silt loam } \\
\text { Hagerstown loam }\end{array}$ & $\begin{array}{l}\text { Spindletop, Tex } \\
\text { League City, Tex. } \\
\text { Atlanta, Ga } \\
\text { Cincinnati, Ohio } \\
\text { Baltimore, Md.... }\end{array}$ & $\begin{array}{l}\text { Sinclair-Prairie Pipe Line Co. of Texas. } \\
\text { Humble Pipe Line Co. } \\
\text { Atlanta Water Department. } \\
\text { Union Gas and Electric Co. } \\
\text { Baltimore Water Department. }\end{array}$ \\
\hline $\begin{array}{l}56 \\
57 \\
58\end{array}$ & $\begin{array}{l}\text { Lake Charles clay-.......... } \\
\text { Merced clay adobe... } \\
\text { Muck. }\end{array}$ & $\begin{array}{l}\text { E1 Vista, Tex } \\
\text { Tranquillity, Calif.-. } \\
\text { New Orleans, La...- }\end{array}$ & $\begin{array}{l}\text { Gulf Pipe Line Co. } \\
\text { Standard Oil Co. of California. } \\
\text { Sewerage and Water Board of New }\end{array}$ \\
\hline $\begin{array}{l}59 \mathrm{~b} \\
60\end{array}$ & Peat & 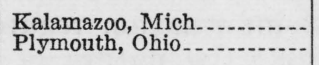 & $\begin{array}{l}\text { Department of Public Utilities. } \\
\text { Ohio Fuel Gas Co. }\end{array}$ \\
\hline $\begin{array}{l}61 \\
62 \\
63 \\
64 \\
65\end{array}$ & $\begin{array}{l}\text { Sharkey clay } \\
\text { Susquehanna clay. } \\
\text { Tidal marsh } \\
\text { Salinas loamy sand. } \\
\text { Alkali soil. }\end{array}$ & $\begin{array}{l}\text { New Orleans, La } \\
\text { Meridian, Miss } \\
\text { Charleston, S, C } \\
\text { Cholame Flats, Calif. } \\
\text { Wilmington, Calif }\end{array}$ & $\begin{array}{l}\text { New Orleans Public Service Co. } \\
\text { Water Department. } \\
\text { Do. } \\
\text { Union Oil Co. } \\
\text { Shell Oil Co. }\end{array}$ \\
\hline $\begin{array}{l}66 \\
67 \\
68 \mathrm{a} \\
69 \mathrm{a}\end{array}$ & $\begin{array}{l}\text { Mohave sandy loam } \\
\text { Cinders. } \\
\text { Gila clay } \\
\text { Alkali soil }\end{array}$ & $\begin{array}{l}\text { Phoenix, Ariz } \\
\text { Milwaukee, Wis......... } \\
\text { Phoenix, Ariz } \\
\text { Wilmington, Calif }\end{array}$ & $\begin{array}{l}\text { Phoenix Water Department. } \\
\text { Milwaukee Gas Light Co. } \\
\text { Phoenix Water Department. } \\
\text { Shell Oil Co. }\end{array}$ \\
\hline
\end{tabular}

a Incomplete sets, mostly ferrous materials.

b No specimens removed in 1934 .

In order to get some of the tables into compact form it has been necessary to refer to the materials by symbols. These are given in table 2. It will be noticed that more than one material has been assigned the same letter. To determine the significance of a letter it is, therefore, necessary to know the size or class of material involved.

TABLE 2.-Identification of specimens

$1 \frac{1}{2}$-INCH PIPE, 5 INCHES LONG

\begin{tabular}{|c|c|c|}
\hline $\begin{array}{l}\text { Identification } \\
\text { letters }\end{array}$ & Material & $\begin{array}{l}\text { Nominal } \\
\text { thickness }\end{array}$ \\
\hline b & $\begin{array}{l}\text { Open-hearth iron, lap-welded } \\
\text { Hand-puddled wrought iron, butt-welded. } \\
\text { Bessemer steel, butt-welded--jeed butt-welded. } \\
\text { Treated Bessemer steel, scale-free, but }\end{array}$ & $\begin{array}{r}\text { Inch } \\
0.145 \\
.145 \\
.145 \\
.145\end{array}$ \\
\hline
\end{tabular}

3-INCH PIPE, 5 INCHES LONG

\begin{tabular}{|c|c|c|}
\hline $\begin{array}{l}\mathrm{A} \\
\mathrm{B} \\
\mathrm{M} \\
\mathrm{N} \\
\mathrm{Y}\end{array}$ & $\begin{array}{l}\text { Open-hearth iron } \\
\text { Hand-puddled wrought iron } \\
\text { Open-hearth steel. } \\
\text { Bessemer steel } \\
\text { Bessemer steel, scale-free, butt-welded } \\
\text { Open-hearth steel, } 0.2 \text { percent of copper }\end{array}$ & $\begin{array}{r}0.216 \\
.216 \\
.216 \\
.216 \\
.216 \\
.216\end{array}$ \\
\hline
\end{tabular}

6-INCH CAST-IRON PIPE, 5 INCHES LONG

\begin{tabular}{l|l|r|}
\hline A & Southern cast iron \\
deLavaud centrifugal process & \\
deLavaud centrifugal process, outside only exposed to soil & Monocast centrifugal process & 0.480 \\
.450 \\
I
\end{tabular}


TABLE 2.-Identification of specimens-Continued

MISCELLANEOUS FERROUS CASTINGS

\begin{tabular}{|c|c|c|}
\hline $\begin{array}{l}\text { Identification } \\
\text { letters }\end{array}$ & Material & $\begin{array}{l}\text { Nominal } \\
\text { thickness }\end{array}$ \\
\hline E. & Cast-steel elbow, 2-inch. & Inch \\
\hline $\mathrm{S}$ & Malleable-iron elbow, 2-inch & \\
\hline 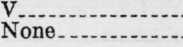 & $\begin{array}{l}\text { High-tensile cast-iron nipple, } 21 / 2-i n c h ~ O . ~ D \\
\text { High silicon cast-iron, } 3 \text { by } 6 \text { inch }\end{array}$ & 0.5 \\
\hline
\end{tabular}

MISCELLANEOUS WROUGHT MATERIALS

\begin{tabular}{|c|c|c|}
\hline $\begin{array}{l}\mathrm{C} \\
\mathrm{K} \\
\mathrm{M}\end{array}$ & $\begin{array}{l}26 \% \text { Cr alloy pipe, } 1 \text { by } 6 \text { inch } \\
1.5 \% \text { Cu steel pipe, } 2 \text { by } 17 \text { inch } \\
\text { Wrought-iron pipe, ground surface, } 2 \text { by } 17 \text { inch } \\
\text { Wrought-iron pipe, mill-scale surface, } 2 \text { by } 17 \text { inch. } \\
\text { Bessemer steel pipe, ground surface, } 2 \text { by } 17 \text { inch } \\
\text { Bessemer steel pipe, mill-scale surface, } 2 \text { by } 17 \text { inch }\end{array}$ & $\begin{array}{r}9.250 \\
.185 \\
.185 \\
.185 \\
.140 \\
.185\end{array}$ \\
\hline
\end{tabular}

FERROUS MATERIALS BURIED IN 1932 ( $11 \frac{1}{2}$ by 12 inches long, except as noted)

[See table 16 for analyses of materials]

\begin{tabular}{|c|c|c|}
\hline $\begin{array}{l}\mathrm{A} \\
\mathrm{B} \\
\mathrm{D} \\
\mathrm{E} \\
\mathrm{F}\end{array}$ & 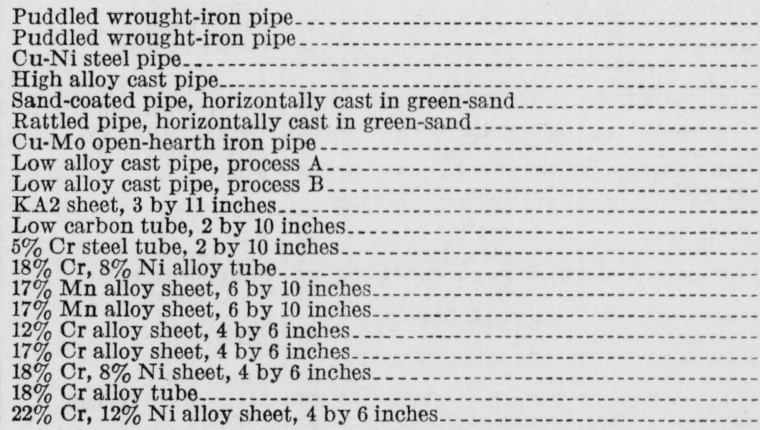 & $\begin{array}{r}0.145 \\
.145 \\
.145 \\
.250 \\
.250 \\
.250 \\
.145 \\
.350 \\
.350 \\
.025 \\
.154 \\
.154 \\
.145 \\
\pm .063 \\
\pm .063 \\
\pm .063 \\
\pm .063 \\
\pm .063 \\
.145 \\
.063\end{array}$ \\
\hline
\end{tabular}

3/4-INCH BOLTS, 4 INCHES LONG, WITHOUT NUTS

\begin{tabular}{l|l|l|} 
Decarburized iron (malleable) & \\
Malleable iron & High-strength malleable iron & \\
Steel &
\end{tabular}

3/4-INCH STEEL BOLTS, 3-INCHES LONG, WITH NUTS

\begin{tabular}{|l|l|l|}
\hline Bare & \\
Lead-coated & Sherardized &
\end{tabular}

In order to get the data for all of the materials in one soil into compact form it has been necessary to refer to the soils by number rather than by name. The names of all the soils and their approximate locations are given in table 3. In using this table it should be remembered that that part of the name which indicates the texture of the soil refers to the texture of the first 6 to 8 inches, i. e., to the A horizon and not to the texture of the soil in which the pipes were placed, 
It should also be remembered that usually several quite different soils are to be found within the boundaries of a city. For example, there is very little Susquehanna clay in Meridian, Miss., near which the test of Susquehanna clay is conducted. The rates of corrosion should not be associated with the cities named but only with soil types.

TABLE 3.-Soils and locations

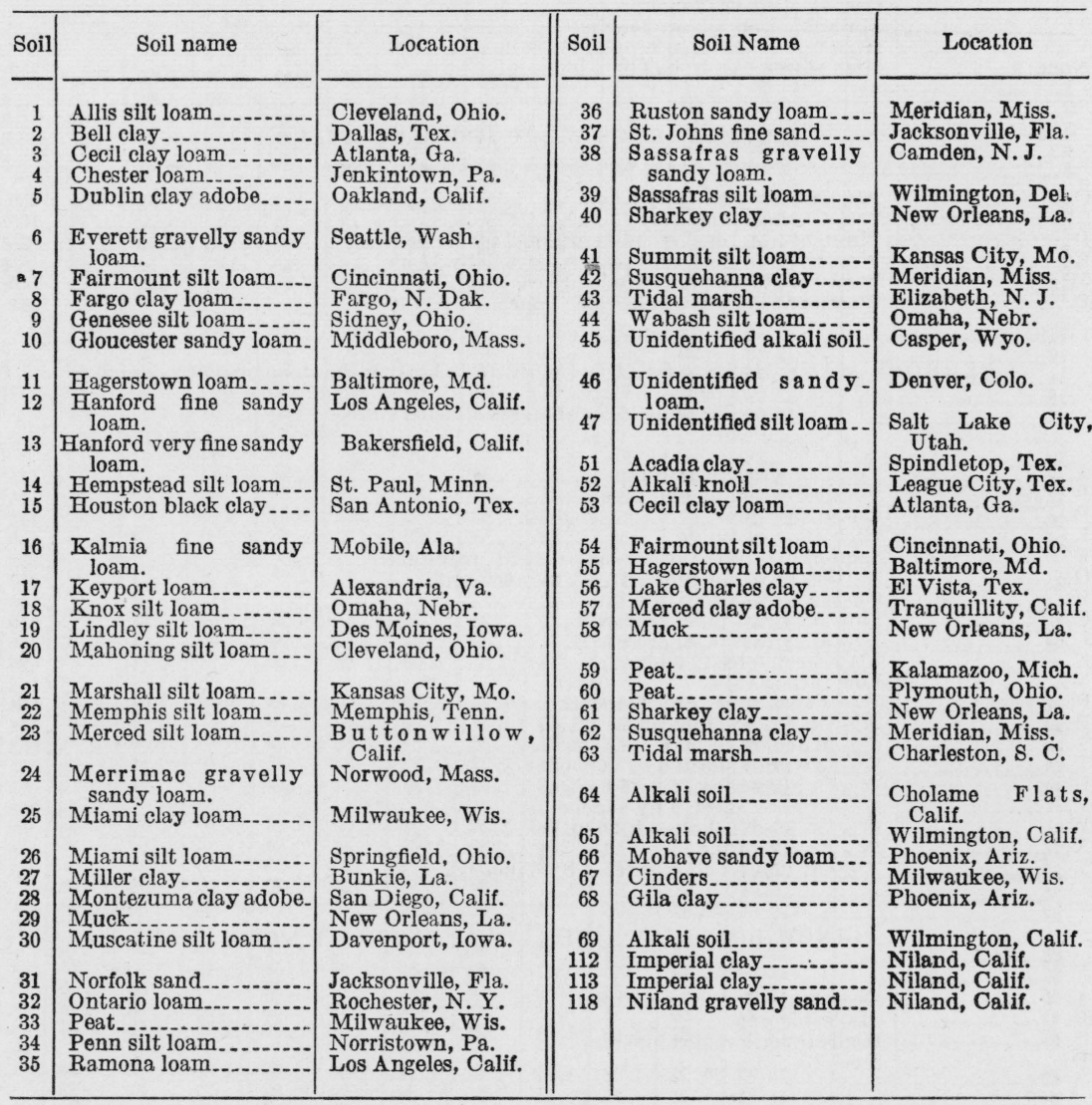

s The correct classification of the soil at this location is in doubt.

\section{PRESENTATION AND DISCUSSION OF THE DATA ON 12-YEAR-OLD SPECIMENS}

\section{RATES OF LOSS OF WEIGHT}

The rates of loss of weight of the 12-year-old specimens, in ounces per square foot per year, are given in table 4. Rates of loss of weight furnish a fairly satisfactory basis for the comparison of materials exposed for the same period to the same soils and for the comparison of the corrosivities of different soils at the close of a given test period. For different periods of test the relative corrosivities of two soils may not be the same since in one soil the initial rate of loss may be maintained, while in another soil the rate may decrease because of the effect of the corrosion products or the settling of the soil in the trench. 
TABLE 4.-Average rates of loss of weight of 12-year-old specimens of ferrous pipe ${ }^{\mathrm{s}}$

[In ounces per square foot per year]

\begin{tabular}{|c|c|c|c|c|c|c|c|c|c|c|c|c|}
\hline \multirow{2}{*}{ Soil } & \multirow{2}{*}{$\begin{array}{c}\text { Duration } \\
\text { of test }\end{array}$} & \multicolumn{4}{|c|}{$\begin{array}{l}\text { 112-inch wrought } \\
\text { specimens }\end{array}$} & \multicolumn{4}{|c|}{$\begin{array}{l}\text { 3-inch wrought } \\
\text { specimens }\end{array}$} & \multicolumn{3}{|c|}{$\begin{array}{l}\text { 6-inch cast-iron } \\
\text { specimens }\end{array}$} \\
\hline & & a & b & e & $y$ & B & $\mathbf{K}$ & M & $\mathrm{Y}$ & $\mathrm{C}$ & $\mathrm{L}$ & $\mathrm{Z}$ \\
\hline & $\begin{array}{c}\text { Years } \\
11.65 \\
12.01 \\
12.10 \\
12.00 \\
12.10\end{array}$ & $\begin{array}{r}0.77 \\
.50 \\
.31 \\
.59 \\
.53\end{array}$ & $\begin{array}{r}0.75 \\
.59 \\
.41 \\
.55 \\
.63\end{array}$ & $\begin{array}{r}0.60 \\
.48 \\
.39 \\
.56 \\
.58\end{array}$ & $\begin{array}{r}0.80 \\
.49 \\
.43 \\
.52 \\
.45\end{array}$ & $\begin{array}{r}0.82 \\
.53 \\
.38 \\
.59 \\
.53\end{array}$ & $\begin{array}{l}0.81 \\
.45 \\
.34 \\
.58 \\
.60\end{array}$ & $\begin{array}{r}0.99 \\
.55 \\
.36 \\
.58 \\
.60\end{array}$ & $\begin{array}{r}0.76 \\
.49 \\
.38 \\
.62 \\
.59\end{array}$ & $\begin{array}{r}1.09 \\
\circ .64 \\
\circ .32 \\
\text { ०1. } 1.00 \\
\text { ॰1. } 04\end{array}$ & $\begin{array}{r}1.16 \\
.56 \\
.33 \\
.90 \\
.70\end{array}$ & $\begin{array}{r}1.12 \\
.42 \\
.35 \\
.84 \\
.87\end{array}$ \\
\hline 0 & $\begin{array}{l}12.09 \\
11.52 \\
11.76 \\
11.51 \\
11.95\end{array}$ & $\begin{array}{l}.08 \\
.43 \\
.71 \\
.41 \\
.36\end{array}$ & $\begin{array}{l}.10 \\
.45 \\
.59 \\
.41 \\
.46\end{array}$ & $\begin{array}{l}.12 \\
.43 \\
.65 \\
.45 \\
.41\end{array}$ & $\begin{array}{l}.08 \\
.37 \\
.55 \\
.43 \\
.36\end{array}$ & $\begin{array}{l}.09 \\
.42 \\
.74 \\
.42 \\
.40\end{array}$ & $\begin{array}{l}.09 \\
.43 \\
.68 \\
.44 \\
.37\end{array}$ & $\begin{array}{l}.13 \\
.49 \\
.71 \\
.40 \\
.41\end{array}$ & $\begin{array}{l}.11 \\
.49 \\
.75 \\
.41 \\
.43\end{array}$ & $\begin{array}{r}.08 \\
.59 \\
1.43 \\
.59 \\
.46\end{array}$ & $\begin{array}{r}.08 \\
.49 \\
1.72 \\
.53 \\
.48\end{array}$ & $\begin{array}{r}.10 \\
.70 \\
2.62 \\
.57 \\
.44\end{array}$ \\
\hline 11. & $\begin{array}{l}11.92 \\
12.10 \\
11.76 \\
12.02 \\
12.00\end{array}$ & $\begin{array}{l}.14 \\
.28 \\
.35 \\
.67 \\
.69\end{array}$ & $\begin{array}{l}.23 \\
.37 \\
.39 \\
.71 \\
.69\end{array}$ & $\begin{array}{l}.17 \\
.34 \\
.44 \\
.64 \\
.67\end{array}$ & $\begin{array}{l}.16 \\
.32 \\
.39 \\
.65 \\
.61\end{array}$ & $\begin{array}{l}.17 \\
.33 \\
.41 \\
.69 \\
.64\end{array}$ & $\begin{array}{l}.17 \\
.30 \\
.36 \\
.68 \\
.63\end{array}$ & $\begin{array}{l}.15 \\
.30 \\
.39 \\
.68 \\
.63\end{array}$ & $\begin{array}{l}.18 \\
.27 \\
.40 \\
.76 \\
.63\end{array}$ & $\begin{array}{l}.14 \\
\text { (d) } \\
.34 \\
0.82 \\
\text { (d) }\end{array}$ & $\begin{array}{l}.17 \\
.47 \\
.42 \\
.70 \\
.84\end{array}$ & $\begin{array}{l}.19 \\
.37 \\
.52 \\
.57 \\
.76\end{array}$ \\
\hline , & $\begin{array}{l}11.78 \\
11.71 \\
11.63 \\
11.65 \\
11.65\end{array}$ & $\begin{array}{l}.80 \\
.25 \\
.25 \\
.57 \\
.60\end{array}$ & $\begin{array}{l}.73 \\
.23 \\
.30 \\
.56 \\
.66\end{array}$ & $\begin{array}{l}.71 \\
.26 \\
.33 \\
.52 \\
.70\end{array}$ & $\begin{array}{l}.77 \\
.23 \\
.29 \\
.52 \\
.61\end{array}$ & $\begin{array}{l}.90 \\
.17 \\
.28 \\
.48 \\
.68\end{array}$ & $\begin{array}{l}.87 \\
.23 \\
.30 \\
.53 \\
.59\end{array}$ & $\begin{array}{l}.82 \\
.21 \\
.29 \\
.52 \\
.67\end{array}$ & $\begin{array}{l}.85 \\
.33 \\
.30 \\
.49 \\
.60\end{array}$ & $\begin{array}{l}.93 \\
.23 \\
.27 \\
.53 \\
.79\end{array}$ & $\begin{array}{l}.78 \\
.23 \\
.47 \\
.66 \\
.71\end{array}$ & $\begin{array}{l}.82 \\
.41 \\
.39 \\
\text { (d) }\end{array}$ \\
\hline 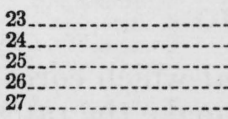 & $\begin{array}{l}12.09 \\
11.95 \\
11.67 \\
11.52 \\
12.02\end{array}$ & $\begin{array}{l}1.67 \\
.11 \\
.29 \\
.31 \\
.59\end{array}$ & $\begin{array}{r}1.75 \\
.11 \\
.34 \\
.37 \\
.71\end{array}$ & $\begin{array}{r}1.64 \\
.13 \\
.30 \\
.31 \\
.73\end{array}$ & $\begin{array}{r}1.69 \\
.12 \\
.25 \\
.30 \\
.63\end{array}$ & $\begin{array}{l}1.71 \\
.10 \\
.24 \\
.35 \\
.69\end{array}$ & $\begin{array}{r}1.62 . \\
.12 \\
.31 \\
.32 \\
.58\end{array}$ & $\begin{array}{r}1.64 \\
.17 \\
.28 \\
.33 \\
.68\end{array}$ & $\begin{array}{r}2.01 \\
.10 \\
.24 \\
.30 \\
.67\end{array}$ & $\begin{array}{r}2.32 \\
.08 \\
.31 \\
.31 \\
01.07\end{array}$ & $\begin{array}{r}3.27 \\
.06 \\
.30 \\
.39 \\
.55\end{array}$ & $\begin{array}{l}\text { (e) } \\
.08 \\
.28 \\
.43 \\
.68\end{array}$ \\
\hline 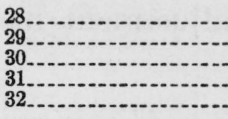 & $\begin{array}{r}9.60 \\
12.04 \\
11.62 \\
12.04 \\
11.66\end{array}$ & $\begin{array}{r}1.63 \\
1.79 \\
.45 \\
.24 \\
.27\end{array}$ & $\begin{array}{r}1.61 \\
1.35 \\
.48 \\
.25 \\
.30\end{array}$ & $\begin{array}{r}1.71 \\
1.60 \\
.41 \\
.24 \\
.28\end{array}$ & $\begin{array}{r}1.75 \\
1.61 \\
.46 \\
.22 \\
.32\end{array}$ & $\begin{array}{r}1.75 \\
1.30 \\
.54 \\
.23 \\
.31\end{array}$ & $\begin{array}{r}1.69 \\
1.49 \\
.50 \\
.23 \\
.31\end{array}$ & $\begin{array}{r}1.62 \\
1.23 \\
.48 \\
.23 \\
.36\end{array}$ & $\begin{array}{r}1.84 \\
1.67 \\
.45 \\
.29 \\
.28\end{array}$ & $\begin{array}{r}0.61 \\
05.28 \\
.80 \\
0.44 \\
.36\end{array}$ & $\begin{array}{r}3.82 \\
2.86 \\
1.08 \\
.19 \\
.35\end{array}$ & $\begin{array}{r}4.00 \\
1.73 \\
.85 \\
.31 \\
.55\end{array}$ \\
\hline 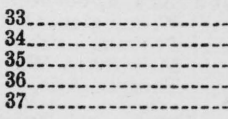 & $\begin{array}{l}11.67 \\
12.00 \\
12.09 \\
12.04 \\
12.04\end{array}$ & $\begin{array}{l}1.21 \\
.32 \\
.14 \\
.21 \\
.69\end{array}$ & $\begin{array}{r}1.20 \\
.40 \\
.22 \\
.27 \\
.75\end{array}$ & $\begin{array}{r}1.23 \\
.34 \\
.18 \\
.27 \\
.64\end{array}$ & $\begin{array}{r}1.22 \\
.26 \\
.09 \\
.24 \\
.58\end{array}$ & $\begin{array}{r}1.23 \\
.49 \\
.15 \\
.19 \\
.69\end{array}$ & $\begin{array}{r}1.00 \\
.36 \\
.14 \\
.23 \\
.70\end{array}$ & $\begin{array}{r}1.10 \\
.44 \\
.21 \\
.20 \\
.75\end{array}$ & $\begin{array}{r}1.20 \\
.40 \\
.16 \\
.20 \\
.86\end{array}$ & $\begin{array}{r}1.36 \\
.63 \\
\circ .26 \\
\circ .36 \\
\circ .20\end{array}$ & $\begin{array}{r}1.39 \\
.58 \\
.17 \\
.16 \\
.78\end{array}$ & $\begin{array}{r}1.70 \\
.63 \\
.54 \\
.24 \\
1.74\end{array}$ \\
\hline$\cdots$ & $\begin{array}{l}12.01 \\
12.00 \\
12.04 \\
11.99 \\
12.03\end{array}$ & $\begin{array}{l}.18 \\
.40 \\
.57 \\
.50 \\
.88\end{array}$ & $\begin{array}{r}.20 \\
.46 \\
.66 \\
.51 \\
1.42\end{array}$ & $\begin{array}{r}.23 \\
.51 \\
.60 \\
.53 \\
1.04\end{array}$ & $\begin{array}{l}.22 \\
.43 \\
.56 \\
.45 \\
.95\end{array}$ & $\begin{array}{l}.20 \\
.52 \\
.71 \\
.54 \\
.74\end{array}$ & $\begin{array}{l}.21 \\
.45 \\
.71 \\
.53 \\
.93\end{array}$ & $\begin{array}{l}.19 \\
.53 \\
.58 \\
.50 \\
.92\end{array}$ & $\begin{array}{r}.22 \\
.42 \\
.70 \\
.50 \\
1.11\end{array}$ & $\begin{array}{r}.18 \\
.73 \\
\circ 1.84 \\
.38 \\
0.59\end{array}$ & $\begin{array}{r}.18 \\
.77 \\
.95 \\
.45 \\
1.48\end{array}$ & $\begin{array}{r}.18 \\
1.19 \\
1.13 \\
.45 \\
2.53\end{array}$ \\
\hline 46 & $\begin{array}{l}12.02 \\
11.61 \\
11.73 \\
12.00 \\
12.08\end{array}$ & $\begin{array}{r}1.29 \\
.25 \\
.83 \\
.33 \\
.19\end{array}$ & $\begin{array}{r}1.38 \\
.35 \\
.77 \\
.42 \\
.33\end{array}$ & $\begin{array}{r}1.62 \\
.41 \\
.83 \\
.37 \\
.25\end{array}$ & $\begin{array}{r}1.47 \\
.30 \\
.79 \\
.37 \\
.23\end{array}$ & $\begin{array}{l}1.18 \\
.30 \\
.90 \\
.39 \\
.27\end{array}$ & $\begin{array}{r}1.06 \\
.24 \\
.96 \\
.36 \\
.25\end{array}$ & $\begin{array}{r}1.09 \\
.29 \\
.79 \\
.40 \\
.23\end{array}$ & $\begin{array}{r}1.35 \\
.27 \\
.95 \\
.40 \\
.26\end{array}$ & $\begin{array}{r}1.69 \\
.32 \\
1.07 \\
.35 \\
.34\end{array}$ & $\begin{array}{c}1.24 \\
.28 \\
\text { (d) } \\
.46 \\
.29\end{array}$ & $\begin{array}{r}1.28 \\
.34 \\
1.28 \\
.67 \\
.35\end{array}$ \\
\hline Avg for all soils. & & .55 & .59 & .57 & .55 & .56 & .55 & .56 & .59 & ใ. 82 & .78 & .84 \\
\hline
\end{tabular}

- See tables 2 and 3 for identification of specimens and soils.

- Includes wrought iron and steel.

- These specimens are approximately 10 years old. Only the outer surface was exposed to the soil.

d No specimens.

- Specimen destroyed; no weight-loss data.

t The average for the C specimens is not comparable with that for the other because of the shorter periods ot exposure.

The same line of reasoning applies also to the rates of pitting, which will be presented in another section of this report. Because of this progressive change in the rates of loss of weight and the rates of penetration, the reader should take into account the data recorded in the reports previously referred to before attempting to estimate the life of a pipe material or the corrosiveness of a soil. It should be remem- 
bered also that the recorded rates are for mechanically cleaned specimens and take no account of the value of the corrosion products as pipe materials, which value is known to be appreciable under some conditions. The conditions of the test under discussion do not permit a numerical expression of this value of corrosion products.

This may account for some of the cases in which the results of the test do not agree with reported field experience. The values given in table 4 are computed from the losses of 2 specimens of each material, except in the cases of the specimens $\mathrm{L}$ and $\mathrm{Z}$. In most cases the losses of the two similar specimens agree quite closely, but occasionally they differ considerably, and in rare instances a specimen may show twice the loss shown by its mate. On this account small differences in the computed rates of loss have no real significance. It will be noted that in many of the soils the rates for the wrought materials (iron and steel) are nearly the same and somewhat smaller than for the cast materials. In different soils the rates differ widely.

From the standpoint of the service which a pipe is expected to render as a carrier of a fluid, the rates of loss of weight are, for most soils, unsatisfactory, since they take no account of the uneven distribution of the loss. Comparison of rates of loss of weight and rates of penetration for different soils will show that there is no close relation between the two, though, of course, pitting involves some loss of weight.

\section{RATES OF PENETRATION BY PITTING}

Table 5 shows the 12-year average maximum rates at which corrosion penetrated the pipe. The values are adjusted to make the rates for specimens of different sizes comparable. This adjustment has been discussed in Research Paper 329, page 8.

TABLE 5.-Weighted average rates of maximum pitting of 12-year-old specimens of ferrous pipe $\mathrm{s}$

[In mils per year]

\begin{tabular}{|c|c|c|c|c|c|c|c|c|c|c|c|c|}
\hline \multirow{2}{*}{ Soil } & \multirow{2}{*}{$\begin{array}{c}\text { Duration } \\
\text { of test }\end{array}$} & \multicolumn{4}{|c|}{$\begin{array}{l}\text { 11/2-inch wrought } \\
\text { specimens }\end{array}$} & \multicolumn{4}{|c|}{$\begin{array}{l}\text { 3-inch wrought } \\
\text { specimens }\end{array}$} & \multicolumn{3}{|c|}{$\begin{array}{l}\text { 6-inch cast-iron } \\
\text { specimens }\end{array}$} \\
\hline & & a & b & $\theta$ & y & B & K & M & $\mathrm{Y}$ & C & L & $\mathbf{Z}$ \\
\hline -. & $\begin{array}{c}\text { Years } \\
11.65 \\
12.01 \\
12.10 \\
12.00 \\
12.10\end{array}$ & $\begin{array}{r}7.9 \\
4.7 \\
7.4 \\
12.5 \\
2.7\end{array}$ & $\begin{array}{l}6.2 \\
4.0 \\
6.6 \\
6.5 \\
4.1\end{array}$ & $\begin{array}{l}7.1 \\
4.6 \\
5.1 \\
6.5 \\
3.5\end{array}$ & $\begin{array}{l}5.8 \\
6.7 \\
4.5 \\
6.8 \\
3.1\end{array}$ & $\begin{array}{l}6.3 \\
4.5 \\
5.3 \\
6.2 \\
3.3\end{array}$ & $\begin{array}{l}7.8 \\
4.3 \\
5.0 \\
8.6 \\
3.8\end{array}$ & $\begin{array}{l}8.2 \\
3.8 \\
5.7 \\
5.9 \\
3.6\end{array}$ & $\begin{array}{r}10.3 \\
4.8 \\
6.4 \\
12.2 \\
3.7\end{array}$ & $\begin{array}{r}9.9 \\
04.2 \\
04.5 \\
010.7 \\
06.0\end{array}$ & $\begin{array}{r}10.5 \\
4.8 \\
9.9 \\
7.5 \\
3.3\end{array}$ & $\begin{array}{r}19.2 \\
7.3 \\
12.1 \\
7.5 \\
7.4\end{array}$ \\
\hline 9 & $\begin{array}{l}12.09 \\
11.52 \\
11.76 \\
11.51 \\
11.95\end{array}$ & $\begin{array}{l}1.9 \\
4.4 \\
8.4 \\
3.7 \\
4.1\end{array}$ & $\begin{array}{l}1.6 \\
3.5 \\
6.5 \\
3.6 \\
4.3\end{array}$ & $\begin{array}{l}1.5 \\
4.3 \\
6.3 \\
2.8 \\
3.3\end{array}$ & $\begin{array}{l}1.4 \\
2.5 \\
4.9 \\
4.5 \\
3.2\end{array}$ & $\begin{array}{l}2.1 \\
4.0 \\
6.8 \\
3.2 \\
3.3\end{array}$ & $\begin{array}{l}1.1 \\
3.8 \\
7.4 \\
4.0 \\
3.8\end{array}$ & $\begin{array}{l}1.8 \\
4.0 \\
5.8 \\
4.3 \\
4.0\end{array}$ & $\begin{array}{l}2.4 \\
3.7 \\
9.3 \\
7.5 \\
4.4\end{array}$ & $\begin{array}{r}\cdot 1.2 \\
7.1 \\
13.3 \\
5.3 \\
3.6\end{array}$ & $\begin{array}{r}.8 \\
7.6 \\
18.5 \\
5.0 \\
5.7\end{array}$ & $\begin{array}{r}.8 \\
6.3 \\
19.4 \\
5.4 \\
5.3\end{array}$ \\
\hline $11 \ldots$ & $\begin{array}{l}11.92 \\
12.10 \\
11.76 \\
12.02 \\
12.00\end{array}$ & $\begin{array}{l}8.3 \\
5.0 \\
8.6 \\
6.5 \\
6.8\end{array}$ & $\begin{array}{l}6.3 \\
4.8 \\
9.3 \\
4.1 \\
5.1\end{array}$ & $\begin{array}{l}5.9 \\
4.5 \\
6.7 \\
4.6 \\
4.8\end{array}$ & $\begin{array}{l}4.9 \\
4.9 \\
7.1 \\
4.4 \\
5.2\end{array}$ & $\begin{array}{r}5.9 \\
5.9 \\
10.0 \\
4.8 \\
4.6\end{array}$ & $\begin{array}{l}5.5 \\
3.9 \\
6.8 \\
5.7 \\
6.3\end{array}$ & $\begin{array}{l}6.4 \\
5.2 \\
7.7 \\
5.5 \\
5.7\end{array}$ & $\begin{array}{l}6.2 \\
6.7 \\
9.3 \\
4.9 \\
6.4\end{array}$ & $\begin{array}{c}3.5 \\
\text { (d) } \\
4.3 \\
03.9 \\
\text { (d) }\end{array}$ & $\begin{array}{r}3.6 \\
4.0 \\
4.3 \\
9.2 \\
12.3\end{array}$ & $\begin{array}{r}5.1 \\
5.4 \\
4.5 \\
7.6 \\
14.2\end{array}$ \\
\hline $\begin{array}{l}17 \\
18 \\
19 \\
20 \\
22\end{array}$ & $\begin{array}{l}11.78 \\
11.71 \\
11.63 \\
11.65 \\
11.65\end{array}$ & $\begin{array}{l}3.5 \\
4.4 \\
4.8 \\
5.8 \\
6.2\end{array}$ & $\begin{array}{l}3.1 \\
3.5 \\
5.3 \\
4.1 \\
5.6\end{array}$ & $\begin{array}{l}3.5 \\
3.4 \\
6.1 \\
6.2 \\
5.9\end{array}$ & $\begin{array}{l}3.3 \\
3.2 \\
5.6 \\
5.5 \\
6.6\end{array}$ & $\begin{array}{l}3.4 \\
3.4 \\
5.3 \\
3.8 \\
4.8\end{array}$ & $\begin{array}{l}3.9 \\
5.2 \\
6.7 \\
6.2 \\
4.6\end{array}$ & $\begin{array}{l}3.8 \\
3.6 \\
4.9 \\
4.7 \\
5.4\end{array}$ & $\begin{array}{l}3.5 \\
3.7 \\
5.0 \\
4.9 \\
5.6\end{array}$ & \begin{tabular}{l|}
6.3 \\
5.9 \\
5.2 \\
7.7 \\
8.4
\end{tabular} & $\begin{array}{r}4.6 \\
7.8 \\
16.1 \\
7.0 \\
13.4\end{array}$ & $\begin{array}{r}5.2 \\
11.5 \\
14.7 \\
9.4 \\
\text { (d) }\end{array}$ \\
\hline
\end{tabular}

See footnotes at end of table. 
TABLE 5.-Weighted average rates of maximum pitting of 12-year-old specimens of ferrous pipe ${ }^{\mathrm{a}}$ - Continued

\begin{tabular}{|c|c|c|c|c|c|c|c|c|c|c|c|c|}
\hline \multirow{2}{*}{ Soil } & \multirow{2}{*}{$\begin{array}{c}\text { Duration } \\
\text { of test }\end{array}$} & \multicolumn{4}{|c|}{$\begin{array}{l}\text { 11/2-inch wrought } \\
\text { specimens b }\end{array}$} & \multicolumn{4}{|c|}{$\begin{array}{l}\text { 3-inch wrought } \\
\text { specimens }\end{array}$} & \multicolumn{3}{|c|}{$\begin{array}{l}\text { 6-inch cast-iron } \\
\text { specimens }\end{array}$} \\
\hline & & a & b & $\theta$ & $y$ & B & $\mathrm{K}$ & M & $\mathrm{Y}$ & $\mathrm{C}$ & $\mathrm{L}$ & $\mathrm{Z}$ \\
\hline $\begin{array}{l}23 \\
24 \\
25 \\
26 \\
27\end{array}$ & $\begin{array}{c}\text { Years } \\
12.09 \\
11.95 \\
11.67 \\
11.52 \\
12.02\end{array}$ & \begin{tabular}{|r|}
12.0 \\
2.3 \\
4.3 \\
3.2 \\
3.5
\end{tabular} & $\begin{array}{r}12.0 \\
1.9 \\
3.7 \\
4.1 \\
3.9\end{array}$ & $\begin{array}{r}12.0 \\
1.8 \\
4.1 \\
3.8 \\
4.9\end{array}$ & $\begin{array}{r}12.0 \\
2.1 \\
2.8 \\
3.0 \\
4.9\end{array}$ & $\begin{array}{r}12.1 \\
2.2 \\
3.8 \\
3.5 \\
4.6\end{array}$ & $\begin{array}{r}12.3 \\
2.2 \\
3.6 \\
3.8 \\
6.3\end{array}$ & $\begin{array}{r}12.0 \\
2.3 \\
4.6 \\
3.1 \\
5.6\end{array}$ & $\begin{array}{r}13.3 \\
2.5 \\
4.2 \\
3.6 \\
5.3\end{array}$ & $\begin{array}{r}18.2 \\
2.8 \\
3.9 \\
6.3 \\
09.0\end{array}$ & $\begin{array}{r}25.1 \\
2.3 \\
7.3 \\
10.0 \\
9.2\end{array}$ & $\begin{array}{r}36.4 \\
2.2 \\
7.8 \\
13.6 \\
9.2\end{array}$ \\
\hline 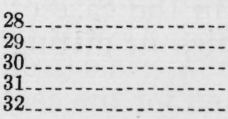 & $\begin{array}{r}9.60 \\
12.04 \\
11.62 \\
12.04 \\
11.66\end{array}$ & $\begin{array}{r}15.1 \\
016.2 \\
4.7 \\
2.7 \\
4.9\end{array}$ & $\begin{array}{r}13.8 \\
7.4 \\
4.4 \\
2.4 \\
3.7\end{array}$ & $\begin{array}{r}14.3 \\
11.3 \\
5.0 \\
2.7 \\
3.9\end{array}$ & $\begin{array}{r}15.1 \\
12.0 \\
4.3 \\
2.5 \\
4.3\end{array}$ & $\begin{array}{r}16.7 \\
9.3 \\
4.6 \\
3.1 \\
5.0\end{array}$ & $\begin{array}{r}18.8 \\
16.1 \\
4.4 \\
3.2 \\
7.0\end{array}$ & $\begin{array}{r}14.8 \\
8.4 \\
5.2 \\
3.0 \\
5.0\end{array}$ & $\begin{array}{r}22.3 \\
14.2 \\
5.4 \\
3.0 \\
7.7\end{array}$ & $\begin{array}{r}\circ 5.9 \\
\circ \quad 7.9 \\
10.6 \\
\circ 3.8 \\
5.8\end{array}$ & \begin{tabular}{r|}
35.6 \\
15.0 \\
10.6 \\
1.5 \\
8.0
\end{tabular} & $\begin{array}{r}17.4 \\
13.5 \\
8.6 \\
5.2 \\
10.3\end{array}$ \\
\hline $3 \ldots$ & $\begin{array}{l}11.67 \\
12.00 \\
12.09 \\
12.04 \\
12.04\end{array}$ & $\begin{array}{l}9.6 \\
4.8 \\
.8 \\
4.6 \\
6.3\end{array}$ & $\begin{array}{l}8.3 \\
3.0 \\
2.0 \\
3.7 \\
5.3\end{array}$ & $\begin{array}{l}7.7 \\
3.4 \\
1.5 \\
4.0 \\
6.5\end{array}$ & $\begin{array}{l}8.9 \\
2.7 \\
.4 \\
3.9 \\
5.6\end{array}$ & $\begin{array}{l}8.5 \\
4.2 \\
2.6 \\
3.7 \\
6.1\end{array}$ & $\begin{array}{l}8.4 \\
2.9 \\
1.6 \\
4.9 \\
5.0\end{array}$ & $\begin{array}{l}7.7 \\
3.7 \\
4.7 \\
3.7 \\
7.6\end{array}$ & $\begin{array}{r}6.8 \\
4.6 \\
1.9 \\
3.6 \\
10.0\end{array}$ & $\begin{array}{r}9.0 \\
7.5 \\
-8.8 \\
-4.3 \\
-8.0\end{array}$ & \begin{tabular}{r|}
13.7 \\
5.5 \\
2.4 \\
4.1 \\
4.7
\end{tabular} & $\begin{array}{r}15.4 \\
4.1 \\
4.1 \\
3.3 \\
8.6\end{array}$ \\
\hline 40 & $\begin{array}{l}12.01 \\
12.00 \\
12.04 \\
11.99 \\
12.03\end{array}$ & $\begin{array}{r}2.9 \\
6.4 \\
11.5 \\
8.4 \\
7.6\end{array}$ & $\begin{array}{l}2.7 \\
4.7 \\
5.7 \\
7.8 \\
7.3\end{array}$ & $\begin{array}{l}2.2 \\
4.1 \\
5.6 \\
6.6 \\
9.2\end{array}$ & $\begin{array}{l}2.5 \\
5.0 \\
6.6 \\
7.6 \\
7.1\end{array}$ & $\begin{array}{l}2.2 \\
5.1 \\
5.4 \\
6.7 \\
6.7\end{array}$ & $\begin{array}{r}1.8 \\
5.7 \\
7.0 \\
5.9 \\
10.3\end{array}$ & $\begin{array}{l}3.0 \\
6.8 \\
5.7 \\
6.1 \\
7.2\end{array}$ & $\begin{array}{l}1.8 \\
8.2 \\
6.0 \\
6.4 \\
8.8\end{array}$ & $\begin{array}{r}1.7 \\
7.9 \\
\text { - } 6.5 \\
3.4 \\
\text { - } 6.3\end{array}$ & $\begin{array}{r}.8 \\
4.8 \\
5.7 \\
4.7 \\
16.0\end{array}$ & $\begin{array}{r}.8 \\
8.3 \\
7.5 \\
5.0 \\
22.8\end{array}$ \\
\hline $\begin{array}{l}43 \\
44 \\
46 \\
46\end{array}$ & $\begin{array}{l}\text { 12. } 02 \\
11.61 \\
11.73 \\
12.00 \\
12.08\end{array}$ & $\begin{array}{l}7.4 \\
7.5 \\
6.9 \\
4.0 \\
1.3\end{array}$ & $\begin{array}{l}6.5 \\
4.8 \\
6.6 \\
5.2 \\
3.6\end{array}$ & $\begin{array}{l}8.3 \\
5.4 \\
7.2 \\
5.3 \\
2.0\end{array}$ & $\begin{array}{l}8.7 \\
5.9 \\
6.9 \\
8.8 \\
2.4\end{array}$ & $\begin{array}{r}10.9 \\
5.3 \\
7.2 \\
5.7 \\
2.3\end{array}$ & $\begin{array}{l}8.8 \\
4.7 \\
9.4 \\
4.7 \\
1.9\end{array}$ & $\begin{array}{l}\text { 6. } 0 \\
6.6 \\
7.9 \\
9.4 \\
2.1\end{array}$ & $\begin{array}{l}5.5 \\
6.1 \\
9.5 \\
6.4 \\
1.9\end{array}$ & $\begin{array}{r}11.8 \\
5.2 \\
9.5 \\
4.6 \\
4.8\end{array}$ & $\begin{array}{c}13.6 \\
5.2 \\
\text { (d) } \\
5.1 \\
.9\end{array}$ & $\begin{aligned} 8.7 \\
5.3 \\
11.2 \\
8.2 \\
2.2\end{aligned}$ \\
\hline A vg. for all soils.- & $\ldots$ & 6. 14 & 5.17 & 5.32 & 5.33 & 5.43 & 5.89 & 5. 61 & 6.44 & f 6.6 & 8.38 & 9. 27 \\
\hline
\end{tabular}

a See tables 2 and 3 for identification of specimens and soils.

Includes wrought iron and steel.

- These specimens are approximately 10 years old.

d No specimens.

- Punctured, 1932 data.

1 The average for the $\mathrm{C}$ specimens is not comparable with that for the other specimens because of the shorter period of exposure.

The discussion of rates in the preceding section is equally applicable to the data in table 5 .

Tables 4 and 5 are presented primarily to enable those who care to do so to interpret the results of the soil-corrosion data as they think best, and to enable them to confirm or contradict the conclusions which the author has drawn. They occupy a position midway between extensive and complicated tables of original observations on the one hand, and tables of computed data involving more or less questionable assumptions on the other. To be of use they must be interpreted. It will be noted that soils differ greatly in corrosiveness and that the relative resistance to corrosion of different materials is not the same for all soils.

\section{PITTING FACTORS}

Under some conditions the unevenness of a corroded surface is of interest. This unevenness is expressed mathematically by the pitting factor, which is the ratio of the depth of the deepest pit to the average thickness of the metal removed by corrosion. The value of this ratio is not a measure of the seriousness of corrosion since the ratio is 1 , both for cases of no corrosion and complete destruction of the material tested. If corrosion were the result of segregations or impuri- 
ties in the metal, the pitting factor would indicate, in a general way, the nonuniform character of the material. In underground corrosion, however, soil characteristics control both the extent and the distribution of the corrosion, and the pitting factor is affected by the character of the soil, and the duration of the exposure, as well as by the character of the material.

A comparison of the average values of the pitting factors in table 6 indicates that the corrosion of the wrought iron is slightly more uniform than that of the other materials, and that the distribution of the corrosion is less uniform on the larger specimens. However, the standard errors indicate the possibility that the differences in the average pitting factors are accidental except, perhaps, in the case of the open-hearth iron. The relation of soil characteristics to pitting factor has been discussed by Denison and Hobbs. ${ }^{5}$

TABLE 6.-Pitting factor for 12-year-old specimens of ferrous pipe

[Ratio of the depth of the deepest pit to the average penetration as determined from loss of weight]

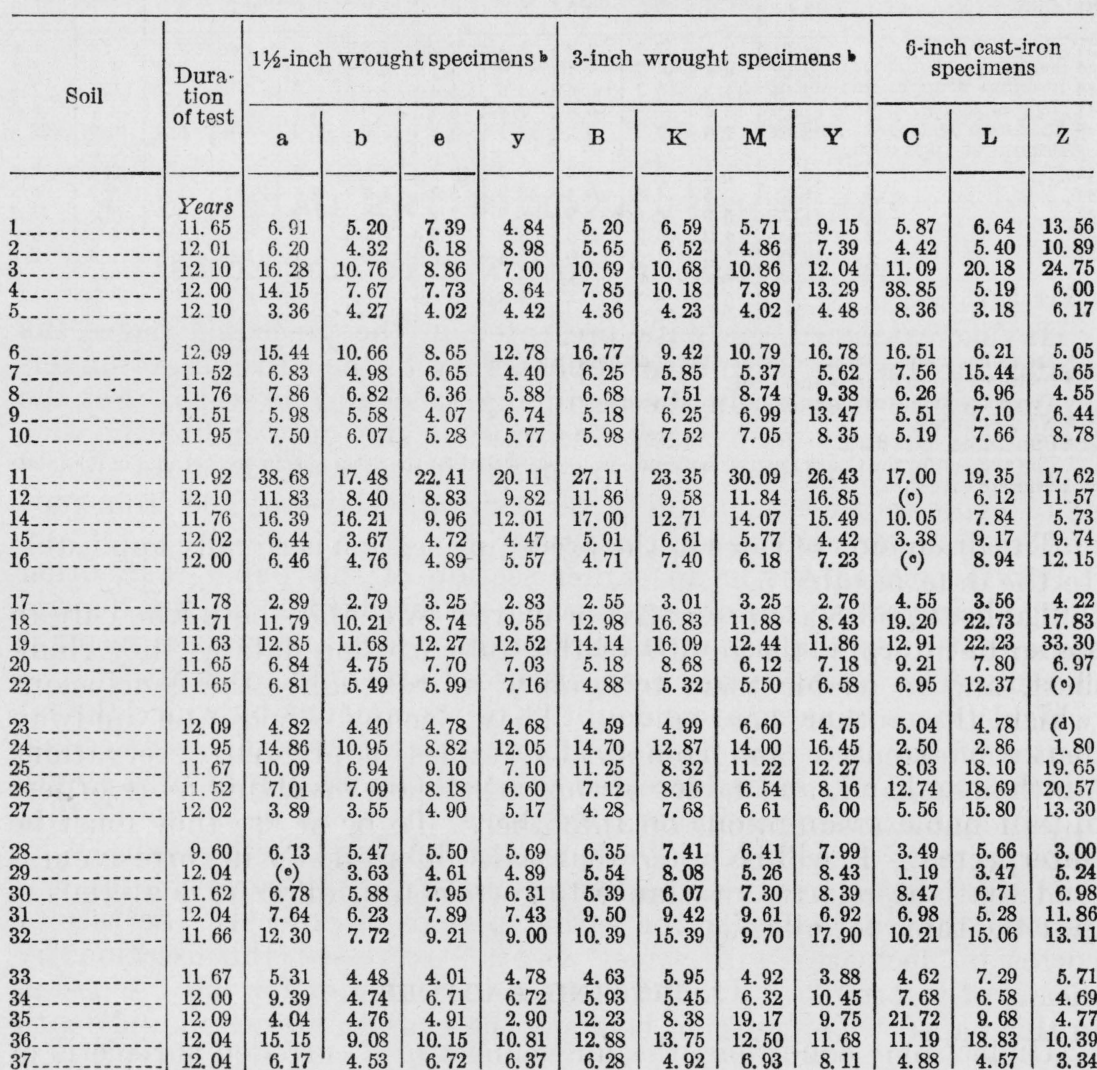

See footnotes at end of table

${ }^{3}$ I. A. Denison and R. B. Hobbs. The corrosion of ferrous metals in acid soils. BS J. Research 13, 125 (1934) RP 696. 
TABLE 6.-Pitting factor for 12-year-old specimens of ferrous pipe a-Continued

[Ratio of the depth of the deepest pit to the average penetration as determined from loss of weight]

\begin{tabular}{|c|c|c|c|c|c|c|c|c|c|c|c|c|}
\hline \multirow{2}{*}{ Soil } & \multirow{2}{*}{$\begin{array}{c}\text { Dura- } \\
\text { tion } \\
\text { of test }\end{array}$} & \multicolumn{4}{|c|}{ 11/2-inch wrought specimens } & \multicolumn{4}{|c|}{ 3-inch wrought specimens b } & \multicolumn{3}{|c|}{$\begin{array}{l}\text { 6-inch cast-iron } \\
\text { specimens }\end{array}$} \\
\hline & & a & b & $\theta$ & y & B & $\mathbf{K}$ & M. & $\mathrm{Y}$ & $\mathrm{C}$ & $\mathrm{L}$ & $\mathrm{Z}$ \\
\hline $\begin{array}{l}38 \\
39 \\
40 \\
41 \\
42\end{array}$ & \begin{tabular}{|l|} 
Years \\
12.01 \\
12.00 \\
12.04 \\
11.99 \\
12.03
\end{tabular} & $\begin{array}{r}10.96 \\
11.11 \\
13.35 \\
11.19 \\
5.92\end{array}$ & $\begin{array}{l}8.77 \\
6.58 \\
5.44 \\
9.81 \\
3.85\end{array}$ & $\begin{array}{l}6.00 \\
5.41 \\
6.27 \\
8.43 \\
5.78\end{array}$ & $\begin{array}{r}7.64 \\
7.61 \\
7.99 \\
11.11 \\
5.11\end{array}$ & $\begin{array}{l}\text { 7. } 73 \\
\text { 7. } 03 \\
5.16 \\
8.61 \\
6.38\end{array}$ & $\begin{array}{l}\text { 5. } 58 \\
8.41 \\
6.97 \\
\text { 7. } 52 \\
7.34\end{array}$ & $\begin{array}{r}13.14 \\
9.60 \\
7.29 \\
8.34 \\
6.00\end{array}$ & $\begin{array}{r}6.47 \\
13.54 \\
5.97 \\
8.77 \\
5.77\end{array}$ & $\begin{array}{l}8.75 \\
7.03 \\
2.20 \\
6.33 \\
6.71\end{array}$ & $\begin{array}{l}2.67 \\
3.80 \\
3.81 \\
6.81 \\
7.59\end{array}$ & $\begin{array}{l}2.67 \\
5.14 \\
4.46 \\
7.22 \\
6.01\end{array}$ \\
\hline $\begin{array}{l}43 \\
44 \\
45 \\
46 \\
47\end{array}$ & \begin{tabular}{|l|}
12.02 \\
11.61 \\
11.73 \\
12.00 \\
12.08 \\
\end{tabular} & $\begin{array}{r}3.96 \\
19.79 \\
5.58 \\
8.01 \\
4.81\end{array}$ & $\begin{array}{l}3.12 \\
9.05 \\
5.56 \\
7.78 \\
7.45\end{array}$ & $\begin{array}{l}3.34 \\
8.83 \\
5.67 \\
9.41 \\
5.71\end{array}$ & $\begin{array}{r}4.28 \\
13.02 \\
5.78 \\
15.50 \\
6.90\end{array}$ & $\begin{array}{r}6.12 \\
12.12 \\
5.27 \\
10.56 \\
6.76\end{array}$ & $\begin{array}{r}6.48 \\
13.73 \\
6.50 \\
9.38 \\
5.25\end{array}$ & $\begin{array}{r}3.67 \\
15.87 \\
7.37 \\
16.42 \\
6.43\end{array}$ & $\begin{array}{r}2.98 \\
15.30 \\
7.24 \\
11.10 \\
5.47\end{array}$ & $\begin{array}{r}4.90 \\
11.35 \\
6.49 \\
9.70 \\
10.43\end{array}$ & $\begin{array}{c}9.47 \\
11.67 \\
\text { (c) } \\
7.08 \\
2.88\end{array}$ & $\begin{array}{r}5.79 \\
10.19 \\
8.30 \\
7.42 \\
4.53\end{array}$ \\
\hline Avg & $-\ldots . .$. & 9.54 & 6.86 & 7. 16 & 7.68 & 8.37 & 8. 63 & 9.04 & 9. 58 & 8.86 & 9.16 & 9. 24 \\
\hline Standard error & & 0.92 & 0.47 & 0.46 & 0.52 & 0.68 & 0.57 & 0.72 & 0.61 & 0.98 & 0.87 & 0.98 \\
\hline
\end{tabular}

a See tables 2 and 3 for identification of specimens and soils.

Includes wrought iron and steel.

- No specimens.

d Specimen destroyed; no weight loss data.

- Punctured, 1932 data.

\section{SIGNIFICANCE OF THE DATA}

\section{APPLICATION OF THE DATA TO PIPE LINES}

Having examined the data presented in the preceding pages the reader may inquire as to their applicability to the corrosion of underground pipe systems. In the beginning, it should be stated that the tests deal directly with rates of corrosion and only indirectly with pipe life. Nevertheless, when properly interpreted, the data should be of value in the estimation of the service to be expected from pipe materials under various soil conditions.

It was pointed out in an earlier section of this paper that, other things being equal, the observed value of the deepest pit will depend somewhat upon the size of the area from which the maximum pit is chosen. This question has been discussed at length by Scott. ${ }^{6}$

While there remains some doubt as to the amount by which the pit depths on the unit area used in this report (the area of $1 \frac{1}{1 / 2}$-inch pipe, 5 inches long) should be increased to equal the pit depths on a length of pipe line exposed to similar conditions, there can be no doubt that some increase is required. The question is being investigated.

It was pointed out in an earlier report on the soil-corrosion investigation ${ }^{7}$ that, at least for the earlier periods of exposure, the rate of corrosion decreases with time. Scott ${ }^{8}$ expressed this relation by means of a formula. The problem is too complex for full discussion in this paper. The relation between the average maximum pit depth

${ }^{6}$ G. N. Scott. Adjustment of soil corrosion pit depth measurements for size of sample. Proc. API 14, IV, November 1933 , p. 204.

7 K. H. Logan, S. P. Ewing, and C. D. Yeomans. Bureau of Standards soil-corrosion studies. Tech. Pap. BS 22, 447 (1928), T368.

$8 \dot{G}$. N. Scott. A preliminary study of the rates of corrosion of iron in soils. Proc. API 14, IV, November 1933. p. 212 . 
and the length of the exposure of steel specimens to certain soils is shown in figure 2. It will be noted that the shapes of the curves are different for different types of soil. The curves also show the importance of considering the kind of soil to which the pipe is exposed.

In the determination of the rates of penetration the Bureau of Standards specimens were cleaned before they were placed in the soil, and after the specimens were removed from the soil the corrosion products were removed. The data, therefore, represent rates of penetration of the pipe wall by corrosion and not necessarily the rate of decrease in the ability of the material to resist pressure without leaking.

It is probable that working lines are subjected to other influences in addition to those affecting the corrosion of the National Bureau of Standards specimens. Some of these influences may accelerate corrosion, while others may retard it. If these influences are of importance it is to be expected that the corrosion of working lines will be

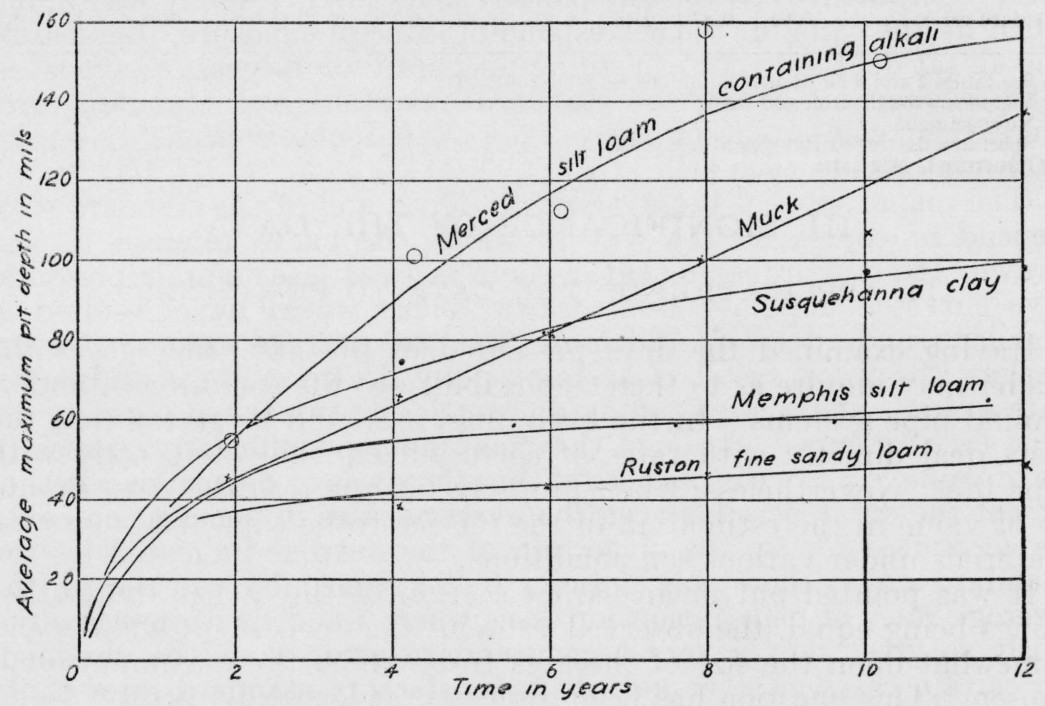

Figure 2.-Relation of pit depth to length of exposure; wrought iron and steel

even more erratic than the corrosion of the specimens under consideration and, as a consequence, that the determination of the average rate of corrosion of working lines will be more difficult. It follows that isolated cases of long or short life of working lines have little significance and that experiments or field observations involving large numbers of observations must be largely depended on for answers to questions regarding corrosion. In any case some means of indicating the dispersion and the reproducibility of the data should be provided.

Doubtless what has just been said regarding the relation of the soilcorrosion data to pipe-line corrosion leaves the reader uncertain as to how he can use the data. This is not because the data are not usable but because, as was said in the introduction to the report, the work is incomplete. So many facts regarding underground corrosion have been collected that it seems probable that a little additional work will yield positive answers to many corrosion problems. 


\section{RELATIVE MERITS OF MATERIALS}

Although the purpose of the original soil-corrosion investigation was to determine the extent to which soils were responsible for corrosion underground, the question as to whether one material is more resistant to soil action than another is of such importance that the soil-corrosion data have been examined with respect to the relative corrosion-resistant properties of the materials tested.

A procedure has been adopted which involves a minimum of assumptions as to similarity of materials, areas, and rates of corrosion. The first step was to plot all of the pit depths for each material in each soil and to draw smooth curves for the data representing the trend of the data with respect to the duration of the exposure. If no specimens were missing, 12 points, 2 for each period of exposure, were plotted.

Points on this curve corresponding to the 6 periods of exposure were taken off, and the ratios of the last point to each of the others were computed. Then each plotted point or pit depth was multiplied by the ratio for the corresponding time of exposure, thus reducing all pit depths to corresponding pit depth for 12 years of exposure. The average pit depth, the standard deviation, and standard error were then computed for these 12 adjusted observations, i. e., for each material in each soil.

The magnitudes of the average pit depth and of the standard error depend of course on the way in which the curve referred to was drawn, and it is probable that in some cases at least more representative curves could have been drawn. This would have resulted in smaller standard errors and more accurate average values. Nevertheless, the worst result of an improperly drawn curve is an inaccurate average and a large standard error. The two taken together are true for any curve, although they may not be sufficiently precise to be of value. Since the purpose of the study was to determine whether or not the differences between the average rates of penetration could be accounted for by the dispersion of the data as indicated by the standard error, there was nothing to be gained by calculating the average rates of penetration for cases where the dispersion was obviously so great that a very large standard error would be obtained. In certain cases an average with a satisfactory standard error could be made by neglecting one or two points on the assumption that such points were the results of abnormal conditions with respect to soil or material. This, however, is a somewhat questionable procedure. Table 7 gives the average maximum pit depths for each material in each soil for which a satisfactory standard error could be computed by the method just outlined. 
TABLE 7.-Estimated average maximum pit depth at 12 years for each material 112/2-INCH WROUGHT IRON AND STEEL $(n=12)$

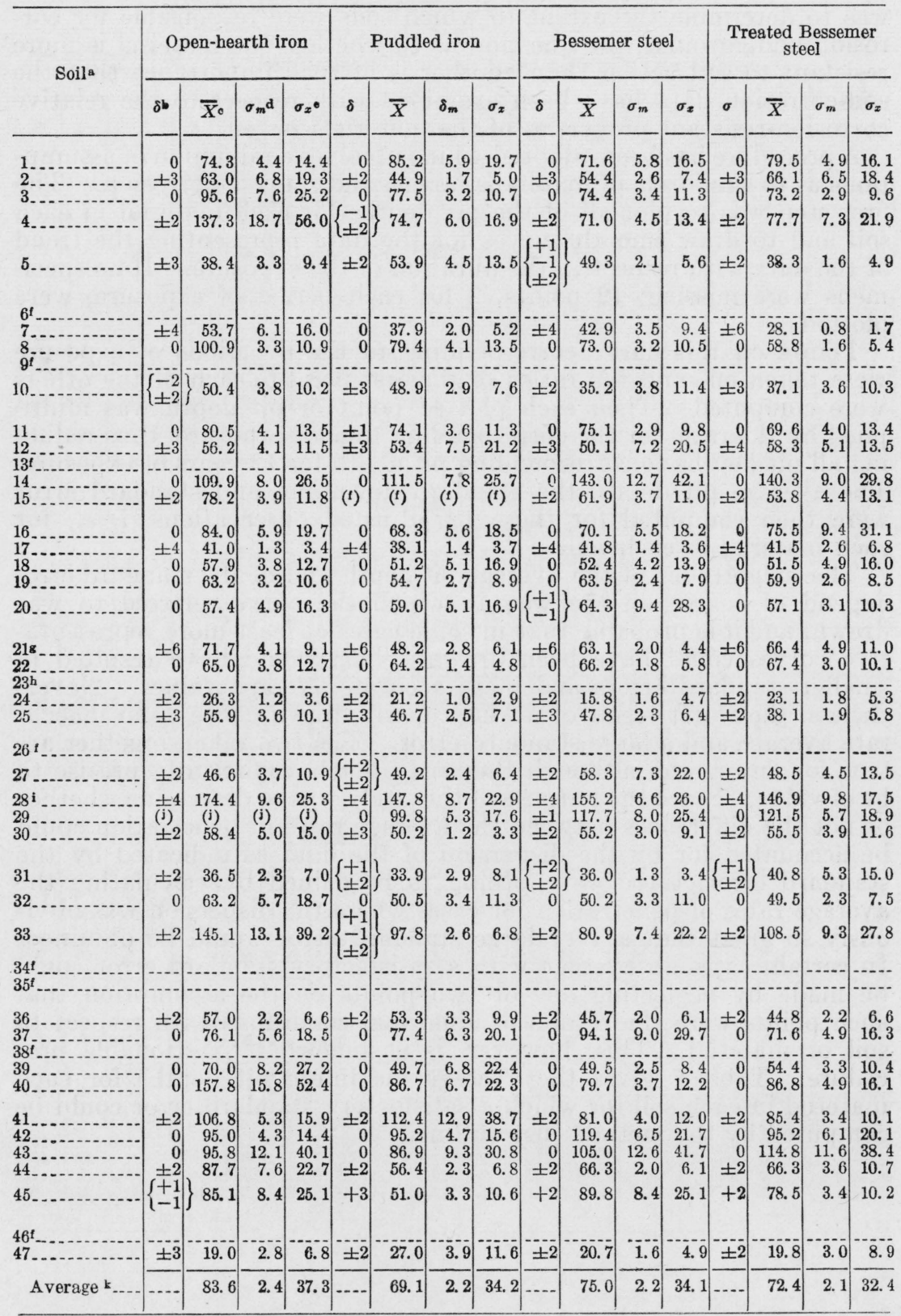

See footnotes at end of table. 
TABLE 7.-Estimated average maximum pit depth at 12 years for each material-Continued

3-INCH WROUGHT IRON AND STEEL $(n=12)$

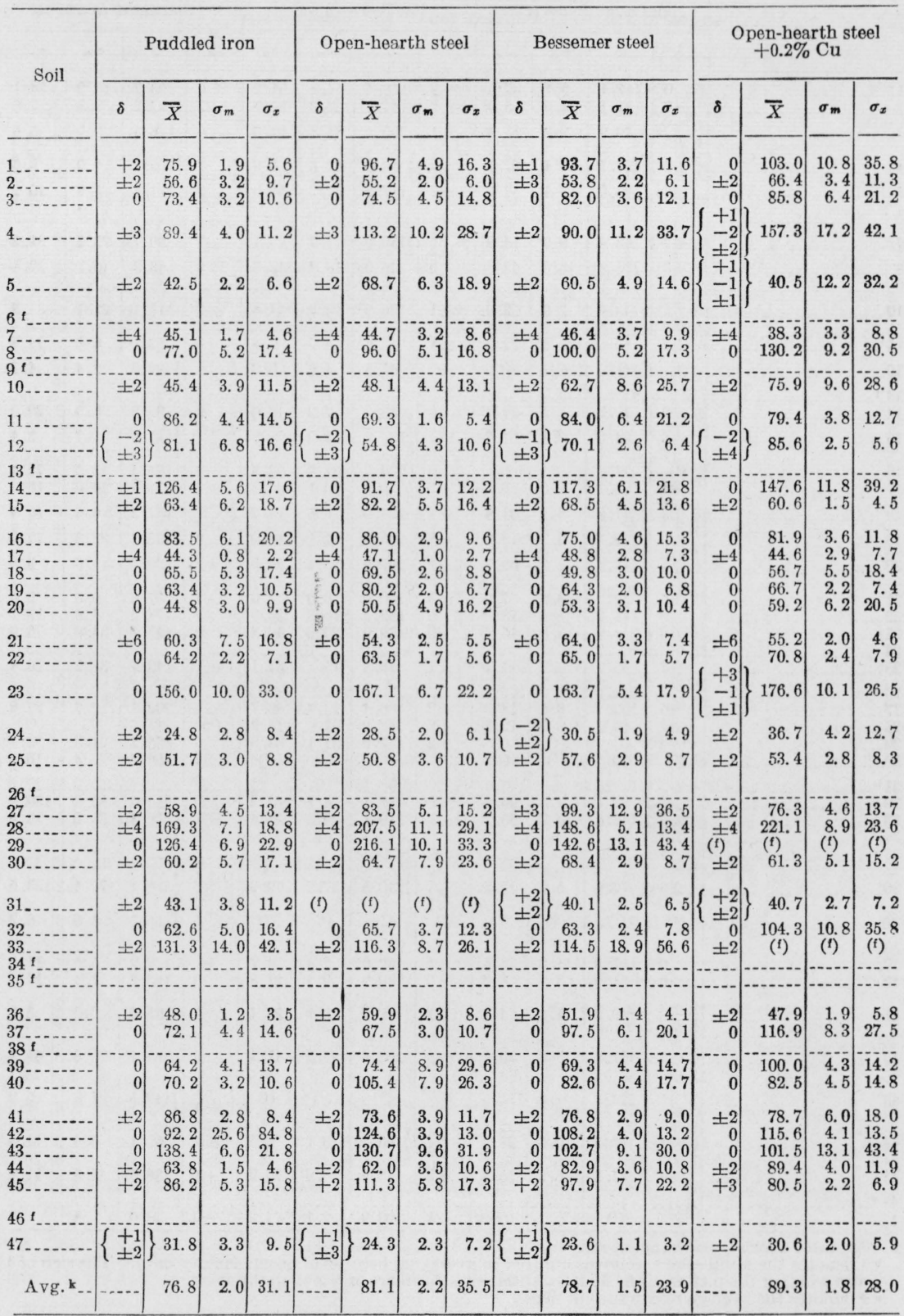

See footnotes at end of table. 
TABLE 7.-Estimated average maximum pit depth at 12 years for each material-Continued

6-INCH CAST IRON

\begin{tabular}{|c|c|c|c|c|c|c|c|c|c|c|c|c|}
\hline \multirow{2}{*}{ oil } & \multicolumn{4}{|c|}{ deLavaud ( $n=12)$} & \multicolumn{4}{|c|}{ Northern $(n=6)$} & \multicolumn{4}{|c|}{ Southern $(n=6)$} \\
\hline & $\delta$ & $\bar{x}$ & $\sigma_{m}$ & $\sigma_{x}$ & $\delta$ & $\bar{x}$ & $\sigma_{m}$ & $\sigma_{x}$ & $\delta$ & $\bar{x}$ & $\sigma_{m}$ & $\sigma_{x}$ \\
\hline- & $\begin{array}{r}0 \\
\pm 7\end{array}$ & $\begin{array}{r}147.1 \\
51.1\end{array}$ & $\begin{array}{l}9.7 \\
3.0\end{array}$ & $\begin{array}{r}32.3 \\
5.9\end{array}$ & $\begin{array}{l}+2 \\
\pm 1\end{array}$ & $\begin{array}{l}158.4 \\
141.5\end{array}$ & $\begin{array}{l}54.4 \\
27.3\end{array}$ & $\begin{array}{l}94.2 \\
54.7\end{array}$ & $\begin{array}{r}0 \\
\pm 1\end{array}$ & $\begin{array}{r}293.7 \\
92.2\end{array}$ & $\begin{array}{r}15.2 \\
3.8\end{array}$ & $\begin{array}{r}34.1 \\
7.6\end{array}$ \\
\hline$\ldots$ & $\left\{\begin{array}{l}+2 \\
\pm 6\end{array}\right.$ & 79.9 & 9.2 & 15.9 & +1 & 295.5 & 34.8 & 69.5 & 0 & 176.5 & 2.7 & 5. 6 \\
\hline & \pm 2 & 127.7 & 10.4 & 27.5 & $\begin{array}{l}+1 \\
\pm 1\end{array}$ & 60.0 & 60.6 & 5.9 & $\left\{\begin{array}{l}-1 \\
\pm 1\end{array}\right.$ & \} 109.8 & 4.9 & 8.6 \\
\hline -- & \pm 6 & 73.0 & 3.5 & 7.9 & \pm 2 & 117.2 & 31.2 & 54.0 & \pm 2 & 111.4 & 5.9 & 10.2 \\
\hline & $\ldots$ & $\ldots$ &.- & $\ldots$ & & & 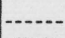 & 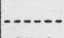 & & $\ldots$ & & . \\
\hline$\cdots$ & \pm 4 & 63.4 & 6.0 & 14.8 & $\begin{array}{l}-1 \\
\pm 2\end{array}$ & 139.9 & 17.7 & 25.1 & \pm 3 & 80.7 & 22.1 & 31.2 \\
\hline 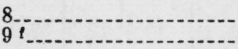 & \pm 3 & 195.8 & 15.0 & 42.5 & 0 & 225.9 & 19.4 & 43.3 & 0 & 43.3 & 10.2 & 22.8 \\
\hline 0. & $\left\{\begin{array}{l}+1 \\
\pm 3\end{array}\right.$ & 43.0 & 2.9 & 8.0 & \pm 1 & 106.9 & 23.9 & 47.8 & \pm 2 & 117.1 & 22.1 & 38.3 \\
\hline & \pm 2 & 84.0 & 24.1 & 72.3 & \pm 1 & 46.6 & 4.9 & 9.8 & 0 & 82.1 & 6.6 & 14.8 \\
\hline ... & (1) & (f) & (1) & (f) & \pm 1 & 41.3 & 4.6 & 9.2 & $\left\{\begin{array}{l}-1 \\
\pm 1\end{array}\right.$ & 89.0 & 2.4 & 4.2 \\
\hline & 0 & 70.3 & 8.3 & 27.7 & 0 & 69.2 & 7.2 & 16.0 & 0 & 69.2 & 8.9 & 20.0 \\
\hline 5 & \pm 6 & 54. 0 & 3.4 & 7.7 & \pm 1 & 137.9 & 14.2 & 28.3 & $\begin{array}{l}+2 \\
+1\end{array}$ & \} 117.1 & 1.7 & 2.4 \\
\hline & $\begin{array}{l}(f) \\
\pm 4\end{array}$ & $\begin{array}{l}(t) \\
95.1\end{array}$ & $\begin{array}{l}\text { (f) } \\
7.6\end{array}$ & $\begin{array}{c}(l) \\
20.2\end{array}$ & $\begin{array}{r}0 \\
\pm 2\end{array}$ & $\begin{array}{r}223.7 \\
78.4\end{array}$ & $\begin{array}{l}27.9 \\
20.1\end{array}$ & \begin{tabular}{|l|}
62.3 \\
36.3
\end{tabular} & $\begin{array}{r}0 \\
\pm 2\end{array}$ & $\begin{array}{r}185.4 \\
71.4\end{array}$ & $\begin{array}{l}43.5 \\
10.9\end{array}$ & $\begin{array}{l}75.4 \\
18.9\end{array}$ \\
\hline 18 & $\left\{\begin{array}{l}-1 \\
\pm 3\end{array}\right.$ & 91.8 & 8.1 & 21.4 & -1 & 124.9 & 6.6 & 13.2 & $\begin{array}{l}-1 \\
\pm 1\end{array}$ & \} 147.2 & 0.5 & 0.9 \\
\hline & & 69.4 & 3.9 & 13.0 & -1 & 205.8 & 5.1 & 10.0 & 0 & 295.3 & 32.3 & 72.2 \\
\hline 20 & $\left\{\begin{array}{l}-2 \\
\pm 2\end{array}\right.$ & \} 119.4 & 37.7 & 99.7 & \pm 1 & 107.9 & 25.4 & 50.9 & \pm 2 & 120.7 & 1.6 & 2.8 \\
\hline & $\begin{array}{r} \pm 6 \\
0\end{array}$ & $\begin{array}{r}52.3 \\
111.2\end{array}$ & & $\begin{array}{r}7.0 \\
18.0\end{array}$ & $\begin{array}{r} \pm 3 \\
0\end{array}$ & $\begin{array}{l}10 \\
16\end{array}$ & & & $\begin{array}{r} \pm 3 \\
0\end{array}$ & & & 0.0 \\
\hline & 0 & 246.9 & 13. & 45.7 & 0 & 339 & & & 0 & & & \\
\hline & \pm 3 & 45.7 & 3.9 & 11.1 & \pm 1 & 85.2 & 15.5 & 31.1 & \pm 1 & 143.9 & 38.2 & 76.4 \\
\hline- & $\begin{array}{l} \pm 6 \\
\pm 9 \\
(\mathrm{f}) \\
\text { (f) }\end{array}$ & $\begin{array}{c}102.7 \\
65.1 \\
(1) \\
(1)\end{array}$ & $\begin{array}{l}8.2 \\
9.0 \\
(i) \\
(f)\end{array}$ & $\begin{array}{c}18.3 \\
12.8 \\
\text { (f) } \\
\text { (f) }\end{array}$ & $\begin{array}{l} \pm 2 \\
\pm 2 \\
\pm 2 \\
(t)\end{array}$ & $\begin{array}{c}383.9 \\
187.0 \\
\text { (i) }\end{array}$ & $\begin{array}{c}67.4 \\
31.1 \\
(f)\end{array}$ & $\begin{array}{c}115.9 \\
53.8 \\
(f)\end{array}$ & $\begin{array}{r}+1 \\
(1) \\
0 \\
\pm 2\end{array}$ & $\begin{array}{c}202.7 \\
(f) \\
168.2 \\
116.7\end{array}$ & $\begin{array}{r}12.7 \\
(1) \\
24.8 \\
9.3\end{array}$ & $\begin{array}{l}22.0 \\
(1) \\
55.4 \\
16.1\end{array}$ \\
\hline & $\begin{array}{l} \pm 1 \\
\pm 2\end{array}$ & $\begin{array}{r}84.1 \\
145.6\end{array}$ & $\begin{array}{r}8.3 \\
15.2\end{array}$ & $\begin{array}{l}26.2 \\
45.7\end{array}$ & $\begin{array}{r}0 \\
\pm 1\end{array}$ & 219.1 & & & $\begin{array}{r}0 \\
\pm 1\end{array}$ & & & $\begin{array}{r}190.0 \\
76.4\end{array}$ \\
\hline & - & & & $\ldots . .$. & 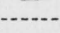 & & & & & & & \\
\hline & & & $\ldots$ & & & & & & & & & $\ldots$ \\
\hline & \pm 6 & 72.0 & 5.5 & 12.2 & $\begin{array}{l}+1 \\
\pm 1\end{array}$ & 246.8 & 57.2 & 99.2 & $\begin{array}{l}+1 \\
\pm 1\end{array}$ & 376.1 & 71.4 & 123.6 \\
\hline & (f) & (i) & (f) & (t) & (f) & (l) & (f) & (t) & $\begin{array}{l}+1 \\
-1\end{array}$ & 115.7 & 4.6 & 6.2 \\
\hline & 0 & $i$ & $\overline{1}$ & 36 & +1 & & & & +1 & & & \\
\hline & \pm 6 & 67.0 & 3. & 8.8 & +1 & & & $\begin{array}{r}4.7 \\
21.8\end{array}$ & $\begin{array}{r} \pm 1 \\
0\end{array}$ & 110.2 & & \\
\hline 11 & $\begin{array}{l}- \\
\pm\end{array}$ & 49.0 & 1.1 & 4.8 & \pm 1 & 68.7 & 10.7 & 21.4 & \pm 1 & 65.5 & 2.9 & 5.9 \\
\hline 12. & $\begin{array}{l}-1 \\
\pm 4\end{array}$ & 137.3 & 13.2 & 29.6 & 0 & 208.6 & 21. 2 & 47.4 & 0 & 269.1 & 28.8 & 64.4 \\
\hline 43. & 0 & 223.8 & 41.0 & 135.8 & (t) & $(1$ & (f) & (I) & $\begin{array}{l} \pm 1 \\
-1\end{array}$ & 142.5 & 4.0 & 6. 9 \\
\hline & \pm 1 & 46.8 & 10.2 & 27.0 & \pm 1 & 65.7 & 3.7 & 6.5 & \pm 1 & 62.4 & 5.6 & 11.3 \\
\hline & +4 & 87.8 & 6.0 & 15.9 & +2 & 132.9 & 5.9 & 10.2 & +1 & 186.0 & 5.8 & 11.7 \\
\hline & (t) & $\left({ }^{(}\right)$ & (t) & (t) & \pm 1 & 20.9 & 2.1 & 4.2 & \pm 2 & 33.0 & .4 & .7 \\
\hline
\end{tabular}

a See table 3 for identification of soils.

b $\delta$ denotes the number of specimens omitted in averaging because of unsatisfactory data. The sign of $\delta$ denotes whether the pitting of the omitted specimens was more or less than the average.

o $\bar{x}$ denotes the average maximum pit depth.

d $\sigma_{m}$ denotes the standard error of $\bar{x}$.

- $\sigma_{x}$ denotes the standard deviation.

$\downarrow$ Data unsatisfactory for determining the pit depth-time curves.

g Specimens lost; average pit depths at the close of 6 years.

b 11/2-inch specimens punctured in less than 8 years.

i Specimens buried late; average pit depths at 10 years.

i Punctured in 8 years.

k Average of the 23 soils with no deletions because of erratic data. 
If all specimens were removed and data from them used, the number of observations or, in statistical terms, the size of the sample was 12 . In some mildly corrosive soils two specimens were left in the ground so that they could be examined after a longer period of exposure. A few specimens were lost or destroyed, and a few pit measurements have been neglected for reasons stated above. The table includes a column showing the number of specimens which were omitted from the computations and the reason for the omission. A \pm sign followed by a number indicates the number of specimens for which no data were available; a + sign and a number indicate that one or more pit measurements were neglected because the values were so much greater than the estimated values for the period that an extremely large standard error would result if the data were included,

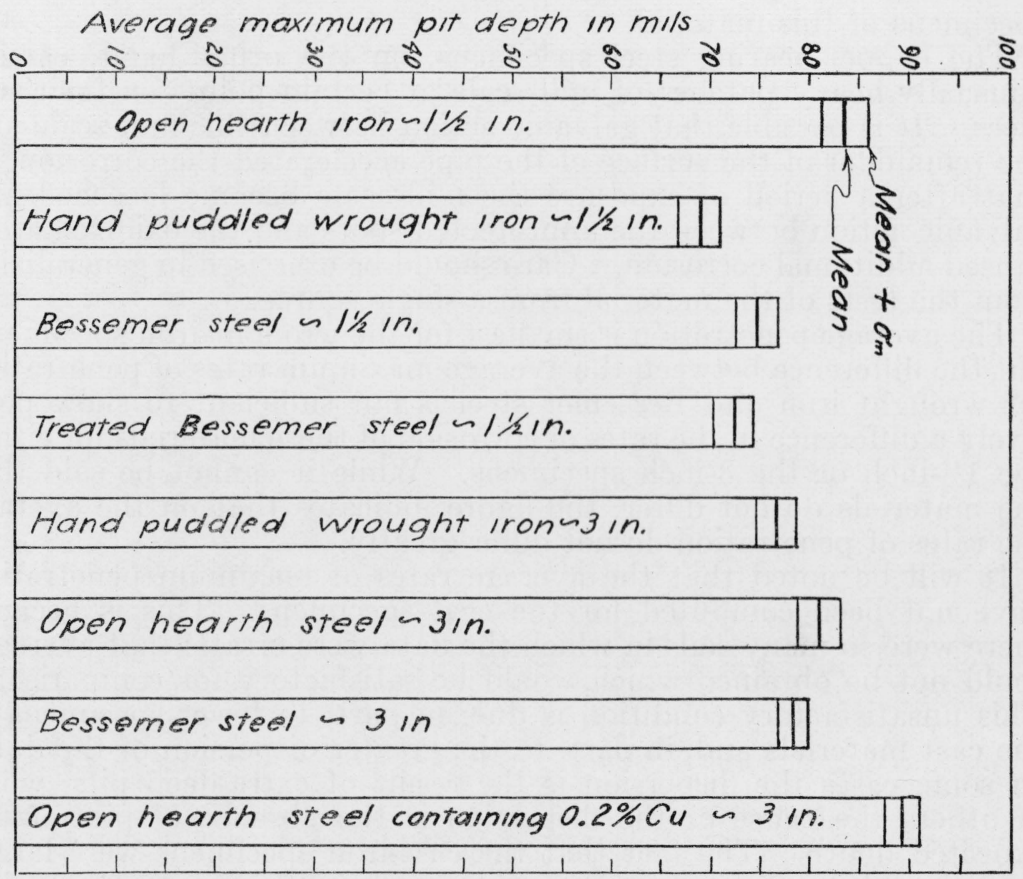

FIGURE 3.-Average maximum pit depth for twelve years of exposure; twenty-three soils.

while a - sign indicates that the pit depth was much less than the estimated value. It is possible, therefore, for anyone to revise the table by eliminating the soils from which data were deleted without completely recalculating the table.

At the bottom of the table the average rates of corrosion for most of the soils are given. The differences in the soils are so great that average rates for all soils have little value, except that they permit a comparison of different materials exposed to the same conditions. These averages have been shown graphically in figure 3 . Since the pit depths were not adjusted to take account of the areas of the specimens only materials of the same size are strictly comparable. 
The figure indicates that there may be a real difference between open-hearth iron specimens and the other $1 \frac{1}{2}$-inch wrought specimens, since the difference between the average pit depth of the iron and that of the other $1 \frac{1}{2}$-inch specimens is approximately twice the sum of the standard errors of the materials. Similarly, the 3-inch openhearth steel containing 0.2 percent of copper may corrode at a different rate from that of the steel to which copper was not added. In both cases the reason for the differences may be the character of the surfaces of the specimens employed, and the conclusions might not apply to materials having similar compositions but different surface finishes. In the case of the open-hearth iron the surfaces of the specimens were covered by an almost continuous thin oxide film which broke down in a relatively few places, thus concentrating the galvanic action. A basis for this suggestion is the low losses of weight of the specimens of this material.

The copper-bearing steel specimens, on the other hand, carried unusually heavy patches of mill scale at certain points on their surfaces. It is possible that galvanic action between this mill scale and the remainder of the surface of the pipe accelerated the corrosion, or that after a period of exposure the mill scale became loosened and galvanic action between the unprotected spots and the oxidized areas caused additional corrosion. Care should be exercised in generalizing from the tests of the material from a single source.

The average penetration is smallest for the wrought-iron specimens, but the difference between the average maximum rates of penetration for wrought iron and Bessemer steel is not sufficient to show positively a difference in the rates of corrosion of these materials for either the $1 \frac{1}{1} 2$-inch or the 3 -inch specimens. While it cannot be said that the materials do not differ, the figure indicates that on the average the rates of penetration do not differ greatly.

It will be noted that the average rates of maximum penetration have not been computed for the cast specimens. This is because there were so many soils in which the data were erratic that averages could not be obtained which would be satisfactory for comparisons. This unsatisfactory condition is due, in part, to fewer specimens of the cast materials and, in part, to the greater dispersion of the data. In some cases the dispersion is the result of extra-deep pits, while in others the cause of the dispersion is the absence of pits of the expected depth. The fact that the cast-iron specimens were larger than the others may to some extent account for the greater dispersion of their data as well as for the greater maximum pit depths that sometimes appear.

Figure 3 indicates also that the maximum pits are generally deeper on the 3 -inch than on the $1 \frac{1}{2}$-inch specimens, but table 7 shows that this is not always the case.

\section{CORROSIVENESS OF SOILS}

Table 7 indicates that so far as the Bureau of Standards data are concerned all of the $1 \frac{1}{2}$-inch materials, with the exception of the open-hearth iron, belong to the same family statistically and that all of the 3-inch specimens, except the steel containing copper, are likewise similar. The data for all similar materials for each soil have been combined for the purpose of showing the relative corrosive- 
ness of some of the soils which have been used, although some of the soils may not be typical of the soil types indicated.

Table 8 is the result and may be regarded as showing the most dependable values of pit depths to be expected on specimens of the sizes used after 12 years of exposure to the soils listed. The standard deviation, which is also given for each soil, indicates how much a single observation may depart from the average value. According to the theory of probability, 95 percent of a series of observations should not differ from the average by more than twice the standard deviation.

TABLE 8.-Estimated average maximum pit depths for specimens of wrought iron and steel in certain soils at 12 years

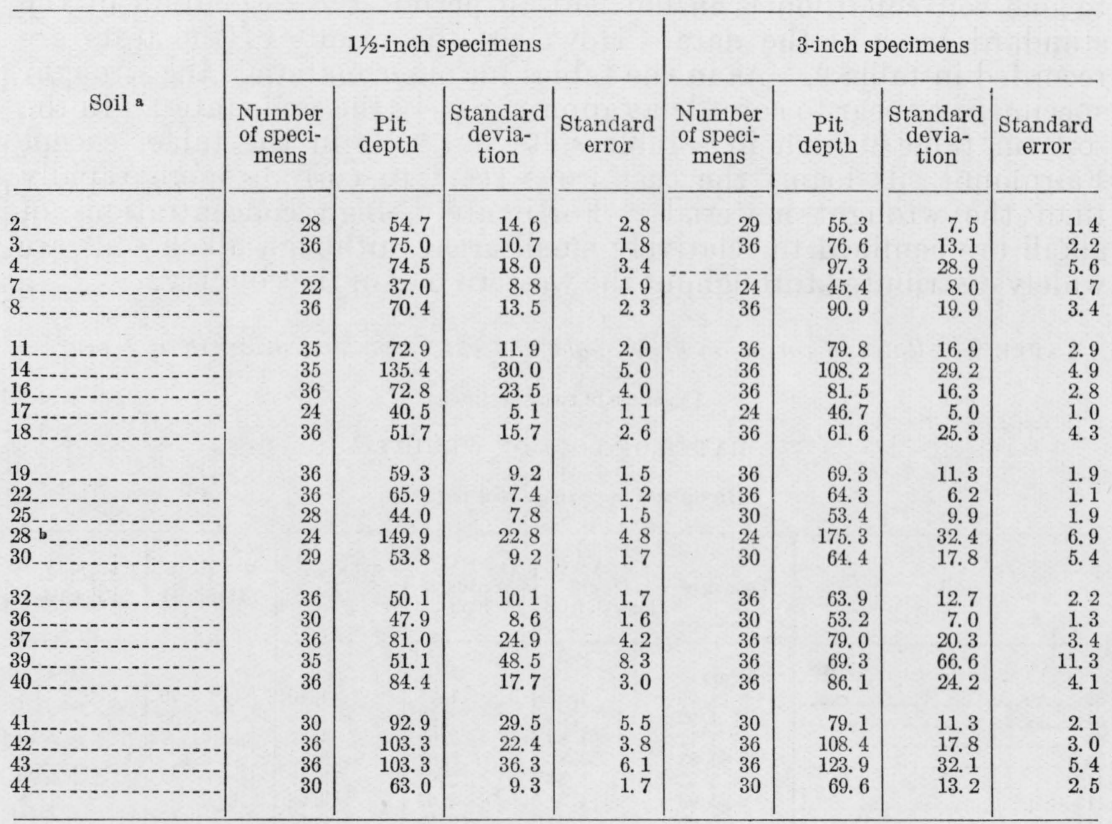

a See table 3 for identification of soils.

b Specimens exposed for 10 years only.

The number of soils for which data are given in table 8 is very small when compared with the several thousand soil series which have been identified. Nevertheless, a considerable variety of soils is represented and some relation between many other soils and those studied can be found. It is expected that a study of the characteristics of the soils tested will result in a knowledge of why they are or are not corrosive, which knowledge will be applicable to soils in general.

To make the data in table 8 of practical use they should be reduced to some standard area and supplemented by additional information by means of which the time required for the puncture of a pipe wall of some assumed thickness could be computed. Since such an adjustment of the data cannot be made at this time the investigation cannot be regarded as completed. 


\section{SPECIAL MATERIALS AND TESTS}

\section{SUPPLEMENTARY TESTS OF PIPES IN CORROSIVE SOILS}

A few soils are of special interest because of their known corrosiveness with respect to some one material, and it seemed desirable to some of those cooperating in the soil-corrosion investigation that several materials be tried out in these corrosive locations primarily for the purpose of finding an inexpensive material suitable for these conditions.

Had the characteristics of underground corrosion been better understood, either more or no specimens would have been placed at these locations, since the number of specimens of one kind exposed to one soil condition is insufficient to permit the estimation of the standard error of the data. However, the results of the tests are recorded in table 9 . As in the tables for older materials the wrought specimens appear to corrode at approximately the same rates. In the soils in table 9 high in soluble salts (all soils in the table, except Fairmount silt loam) the cast irons seem to corrode more rapidily than the wrought materials. Fortunately, high concentrations of alkali are confined to relatively small areas, although alkali soils are widely distributed throughout the western half of the country.

TABLE 9.-Rates of corrosion of wrought and cast pipe buried less than 7 years

[A verage of two specimens]

RATES OF LOSS OF WEIGHT

[In ounces per square foot per year]

\begin{tabular}{|c|c|c|c|c|c|c|}
\hline Soil a & Exposure & $\begin{array}{c}\text { A } \\
\text { Open- } \\
\text { hearth iron }\end{array}$ & $\begin{array}{c}\text { B } \\
\text { Wrought } \\
\text { iron }\end{array}$ & $\underset{\text { Steel }}{\mathrm{N}}$ & $\begin{array}{c}\text { I } \\
\text { Monocast }\end{array}$ & $\begin{array}{l}\text { A and } \mathrm{L} \\
\text { Pit cast }\end{array}$ \\
\hline $\begin{array}{l}52 \\
54 \\
69 \\
112 \\
113 \mathrm{~d}-10 \\
118\end{array}$ & $\begin{array}{c}\text { Years } \\
1.96 \\
1.92 \\
1.72 \\
1.83 \\
5.93 \\
5.93 \\
5.93\end{array}$ & $\begin{array}{l}1.56 \\
.54 \\
1.85 \\
7.82 \\
3.34 \\
4.34 \\
2.69\end{array}$ & $\begin{array}{l}1.75 \\
.53 \\
2.09 \\
7.82 \\
2.84 \\
3.67 \\
2.59\end{array}$ & $\begin{array}{l}1.40 \\
.38 \\
1.67 \\
8.13 \\
3.17 \\
3.98 \\
2.51\end{array}$ & $\begin{array}{l}3.79 \\
.80 \\
\text { (o) } \\
\\
\text { (e) } \\
3.19\end{array}$ & $\begin{array}{r}3.68 \\
.57 \\
2.72 \\
4.70 \\
\text { (e) } \\
4.13\end{array}$ \\
\hline
\end{tabular}

WEIGHTED AVERAGE MAXIMUM RATE OF PENETRATION

[In mils per year]

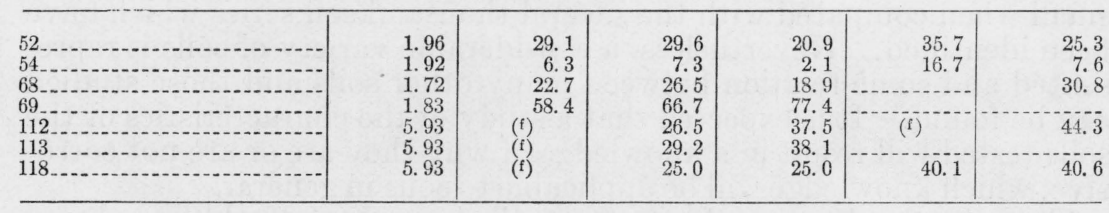

a See table 3 for identification of soils.

b Six specimens of each material were removed from this soil.

- So corroded that a piece of each specimen was broken out when cleaning.

d Same soil as number 112 but with more alkali.

e So corroded that a piece was broken out of one specimen when cleaning.

f Punctured. 
Closely related to the data just presented are observations on a few cast materials buried in corrosive soils in 1924. The data are presented in table 10. They are not sufficient to be more than suggestive, but their presentation is believed to be justified by the scarcity of other data on these commonly used materials. Since the elbows (specimens $\mathrm{V}$ and $\mathrm{S}$ ) had no plane surfaces pit-depth measurements were impracticable. The specimens of Monocast iron, I, were coated with the cement which at that time was used to coat the molds. Since the cement came off when the specimens were cleaned the loss due to corrosion could not be determined.

TABLe 10.-Corrosion of special cast-iron pipe and fittings

\section{RATES OF LOSS OF WEIGHT}

[In ounces per square foot per year]

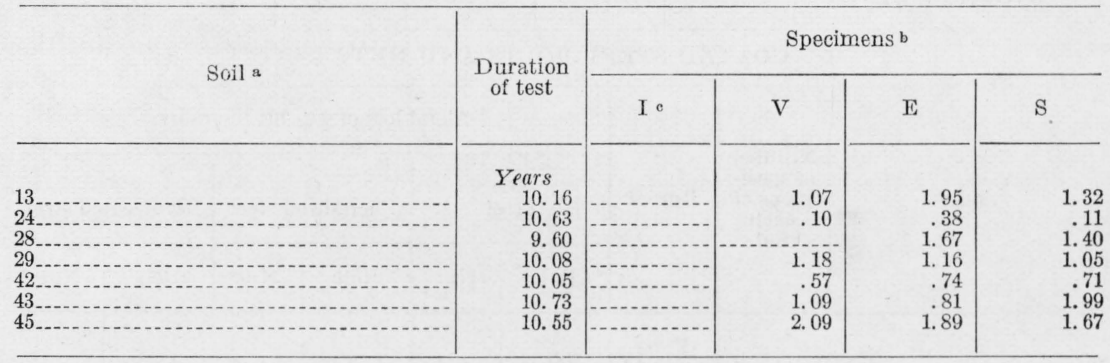

WEIGHTED MAXIMUM RATE OF PITTING

[In mils per year]

\begin{tabular}{|c|c|c|c|c|c|}
\hline $\begin{array}{l}13 \\
24 \\
28 \\
42 \\
45\end{array}$ & $\begin{array}{r}10.16 \\
10.63 \\
9.60 \\
10.08 \\
10.05 \\
10.73 \\
10.55\end{array}$ & $\begin{array}{r}6.2 \\
2.7 \\
14.4 \\
5.2 \\
8.0 \\
17.6 \\
14.7\end{array}$ & $\begin{array}{r}11.7 \\
4.0 \\
8.7 \\
9.2 \\
15.2 \\
13.7\end{array}$ & 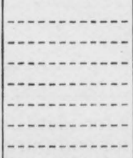 & 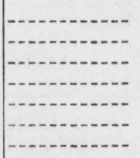 \\
\hline
\end{tabular}

a See table 3 for identification of soils.

- See table 2 for identification of materials.

- These specimens were partially coated with cement in the manufacturing process.

\section{BOLTS}

Since certain types of joints are bolted, requests have been made from time to time for information as to the best types of bolts for underground use, and as a result a few bolts have been included in the tests at a few sites. Table 11 presents the available data on the corrosion of these bolts. Unfortunately, it has not been practicable to measure pit depth or to test the bolts under the stresses to which they would be subjected in service. Since the data cannot be compared with any other, they are presented in the form of average total losses for each set of bolts rather than as rates of loss of weight. It will be seen from the first part of the table that either sherardizing or coating with lead adds materially to the life of bolts in all soils to which they were exposed. Although no measurements of pits were made, inspection indicated that the corrosion was more nearly uniform on the sherardized bolts. The specimens reported on in the first part of the table have not been exposed to soil action long enough to develop positive differences between the materials. 
TABLE 11.-Corrosion $3 / 4$-inch coated bolts

MALLEABLE IRON BOLTS

\begin{tabular}{|c|c|c|c|c|c|c|}
\hline \multirow[b]{2}{*}{ Soil a } & \multirow{2}{*}{$\begin{array}{l}\text { Number of } \\
\text { specimens } \\
\text { of each } \\
\text { kind o }\end{array}$} & \multirow[b]{2}{*}{ Buried } & \multicolumn{4}{|c|}{ Total loss of weight, in grams } \\
\hline & & & $\stackrel{\text { A }}{\begin{array}{c}\text { Decarbur- } \\
\text { ized }\end{array}}$ & $\begin{array}{c}\mathrm{B} \\
\text { Not decar- } \\
\text { burized }\end{array}$ & $\underset{\text { strength }}{\text { High }}$ & $\underset{\text { Steel b }}{\text { D }}$ \\
\hline 65 & $\begin{array}{l}2 \\
2 \\
2 \\
2 \\
2 \\
2 \\
2\end{array}$ & $\begin{array}{r}\text { Years } \\
1.92 \\
1.89 \\
1.91 \\
1.99 \\
.95 \\
1.93 \\
2.04\end{array}$ & $\begin{array}{l}\text { 2. } 80 \\
\text { 3. } 59 \\
\text { 3. } 20 \\
\text { 7. } 96 \\
\text { 2. } 97 \\
\text { 4. } 43 \\
\text { 6. } 72\end{array}$ & $\begin{array}{l}3.86 \\
3.65 \\
3.69 \\
8.98 \\
2.86 \\
5.13 \\
6.64\end{array}$ & $\begin{array}{r}3.11 \\
2.58 \\
4.24 \\
10.15 \\
2.93 \\
5.67 \\
5.17\end{array}$ & $\begin{array}{l}\text { 3. } 02 \\
2.15 \\
4.02 \\
9.58 \\
3.14 \\
3.92 \\
4.18\end{array}$ \\
\hline Average...-. & $\cdots$ & $-\cdots$ & 4. 52 & 4.97 & 4.84 & 4. 29 \\
\hline
\end{tabular}

COATED STEEL BOLTS AND NUTS

\begin{tabular}{|c|c|c|c|c|c|c|c|c|}
\hline \multirow{3}{*}{ Soil a } & \multirow{3}{*}{$\begin{array}{c}\text { Number } \\
\text { of speci- } \\
\text { mens of } \\
\text { each } \\
\text { kind }\end{array}$} & \multirow{3}{*}{ Buried } & \multicolumn{6}{|c|}{ Total loss of weight, in grams } \\
\hline & & & \multicolumn{2}{|c|}{$\underset{\text { Steel }}{\mathrm{D} b}$} & \multicolumn{2}{|c|}{$\begin{array}{c}\mathrm{G} \\
\text { Sheradized steel }\end{array}$} & \multicolumn{2}{|c|}{$\frac{\text { F }}{\text { Lead-coated steel }}$} \\
\hline & & & Bolt & Nut & Bolt & Nut & Bolt & Nut \\
\hline $\begin{array}{l}13 \\
24 \\
42 \\
43 \\
45\end{array}$ & $\begin{array}{l}4 \\
4 \\
1 \\
4 \\
3 \\
4 \\
4\end{array}$ & $\begin{array}{l}\text { Years } \\
10.16 \\
10.63 \\
9.60 \\
10.08 \\
10.05 \\
10.73 \\
10.55\end{array}$ & $\begin{array}{r}24.99 \\
3.04 \\
29.11 \\
23.63 \\
15.30 \\
37.52 \\
16.71\end{array}$ & $\begin{array}{r}8.43 \\
1.29 \\
13.60 \\
9.45 \\
5.41 \\
5.47 \\
5.60\end{array}$ & $\begin{array}{r}3.20 \\
2.37 \\
19.32 \\
13.45 \\
4.47 \\
24.32 \\
15.19\end{array}$ & $\begin{array}{l}1.23 \\
.90 \\
8.63 \\
4.60 \\
1.80 \\
8.05 \\
8.09\end{array}$ & $\begin{array}{r}6.50 \\
1.43 \\
-18.93 \\
6.52 \\
13.05 \\
42.23\end{array}$ & \begin{tabular}{r}
2.02 \\
.78 \\
\hdashline 7.92 \\
2.62 \\
7.54 \\
14.40
\end{tabular} \\
\hline Average _- & $\ldots$ & $-\cdots$ & 21.47 & 7.04 & 11. 76 & 4. 76 & 14. 78 & 5.88 \\
\hline
\end{tabular}

a See table 3 for identification of soils.

b Included for comparison.

- See table 2 for identification of materials.

\section{HIGH-SILICON CAST IRON}

Among the materials offered for the original investigation was a cast iron containing approximately 14 percent of silicon. This material is very resistant to many acids. It is not machinable and is easily chipped if not handled with care. Because of this characteristic a number of specimens submitted have been injured and it has been impossible to determine the loss resulting from corrosion. The surfaces of many of the specimens originally contained numerous dimples or pits formed when the specimens were cast. When the specimens were removed it was in many cases impossible to determine whether or not the observed depressions were the result of corrosion, although the general condition of nearly all of the specimens indicates that pitting was improbable. In only one soil, Montezuma clay adobe, soil 28, were the specimens seriously damaged by corrosion. These specimens were split and definitely corroded along the breaks. Corrosion of the specimens of this material in this soil has been observed each time the specimens were removed. Slight rusting or etching has been observed in a few other locations, but in no other soil has the corrosion appeared to be of any practical importance. Table 12 gives the rates of loss of weight for the highsilicon cast iron. 
TABLE 12.-Average rate of loss of weight of specimens of high-silicon cast iron

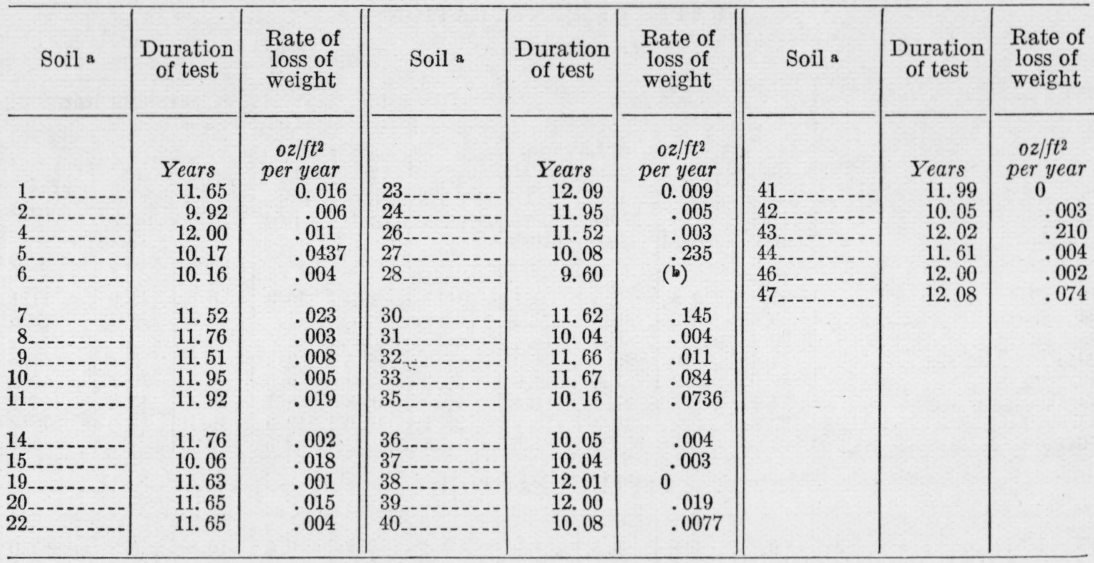

a See table 3 for identification of soils.

b Both specimens cracked by corrosion.

\section{INFLUENCE OF MILL AND FOUNDRY SCALE}

In order to study the influence of the condition of the surface of the material on the rate and distribution of corrosion, specimens of normal material were buried in the same trench with specimens of the same materials from which the original surfaces were removed by a lathe or a grinder which left the surfaces bright. Here, again, the need for economy made it impracticable to use a sufficiently large number of specimens to obtain a very definite result.

Table 13 shows the result of the experiment. Results from copper steel and lead-coated steel are included because it is desirable to compare the data on these specimens with data on specimens belonging to the test without reproducing the latter data.

TABLE 13.-Effect of mill and foundry scale on corrosion

(Period of exposure was approximately 8 years)

RATES OF LOSS OF WEIGHT

[In ounces per square foot per year]

\begin{tabular}{|c|c|c|c|c|c|c|c|c|c|c|}
\hline \multirow{3}{*}{ Soil a } & \multicolumn{4}{|c|}{ Cast iron } & \multicolumn{3}{|c|}{ Steel } & \multicolumn{3}{|c|}{ Wrought iron } \\
\hline & \multicolumn{2}{|c|}{ Pit } & \multicolumn{2}{|c|}{ deLavaud } & \multirow{2}{*}{$\begin{array}{c}\mathrm{C} \\
+1.5 \% \\
\text { copper }\end{array}$} & \multirow{2}{*}{$\begin{array}{c}\mathrm{P} \\
\text { Nor- } \\
\text { mal }\end{array}$} & \multirow{2}{*}{$\begin{array}{c}\text { M } \\
\text { Pol- } \\
\text { ished }\end{array}$} & \multirow[b]{2}{*}{$\begin{array}{c}\text { Lead } \\
\text { coated }\end{array}$} & \multirow[b]{2}{*}{$\begin{array}{c}\mathrm{K} \\
\text { Nor- } \\
\text { mal }\end{array}$} & \multirow[b]{2}{*}{$\underset{\text { Ground }}{\mathrm{D}}$} \\
\hline & $\begin{array}{l}\text { Ab } \\
\text { Nor- } \\
\text { mal }\end{array}$ & $\left|\begin{array}{c}\text { MC } \\
\text { Ma- } \\
\text { chined }\end{array}\right|$ & $\begin{array}{c}\mathrm{C} \\
\text { Nor- } \\
\text { mal }\end{array}$ & $\begin{array}{c}\text { MD } \\
\text { Ma- } \\
\text { chined }\end{array}$ & & & & & & \\
\hline \multirow{6}{*}{$\begin{array}{l}13 \\
24 \\
28 \\
42 \\
43 \\
45 \\
\text { Ratio }{ }^{\circ}-\end{array}$} & $\begin{array}{r}1.12 \\
.11\end{array}$ & $\begin{array}{r}1.29 \\
.13\end{array}$ & $\begin{array}{r}0.05 \\
.17\end{array}$ & $\begin{array}{r}1.10 \\
.16\end{array}$ & $\begin{array}{r}1.13 \\
.21\end{array}$ & & 1.51 & \multirow{6}{*}{$\begin{array}{r}0.18 \\
.78 \\
1.09 \\
.61 \\
.44 \\
.77 \\
1.27 \\
5-5\end{array}$} & $\begin{array}{r}1.12 \\
.22\end{array}$ & $\begin{array}{r}1.01 \\
.18\end{array}$ \\
\hline & 3. 94 & & 1. 14 & & & & & & & \\
\hline & $\begin{array}{r}2.31 \\
.70\end{array}$ & $\begin{array}{r}.99 \\
43\end{array}$ & $\begin{array}{r}5.28 \\
59\end{array}$ & $\begin{array}{r}1.27 \\
.47\end{array}$ & $\begin{array}{r}1.41 \\
.81\end{array}$ & $\begin{array}{r}1.21 \\
89\end{array}$ & $\begin{array}{r}1.06 \\
.94\end{array}$ & & $\begin{array}{r}1.18 \\
88\end{array}$ & $\begin{array}{r}1.22 \\
.80\end{array}$ \\
\hline & 1. 08 & 1. 00 & 3.08 & 1. 20 & .90 & .86 & 1.14 & & .67 & .67 \\
\hline & 3.50 & & 3.55 & 2. 59 & 3.24 & 2.64 & 2.26 & & 2.51 & 2. 17 \\
\hline & 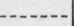 & $3-5$ & & & & & & & & $4-6$ \\
\hline
\end{tabular}

a See table 3 for identification of soils.

- See table 2 for identification of materials.

- Ratio of cases of superiority to total number of cases of comparison. 
TABLE 13.-Effect of mill and foundry scale on corrossion-Continued RATES OF PENETRATION

[In mils per year]

\begin{tabular}{|c|c|c|c|c|c|c|c|c|c|c|}
\hline \multirow{3}{*}{ Soil } & \multicolumn{4}{|c|}{ Cast iron } & \multicolumn{3}{|c|}{ Steel } & \multicolumn{3}{|c|}{ Wrought iron } \\
\hline & \multicolumn{2}{|c|}{ Pit } & \multicolumn{2}{|c|}{ deLavaud } & \multirow[b]{2}{*}{$\begin{array}{c}\mathrm{C} \\
+1.5 \% \\
\text { copper }\end{array}$} & \multirow[b]{2}{*}{$\begin{array}{c}\mathrm{P} \\
\text { Nor- } \\
\text { mal }\end{array}$} & \multirow[b]{2}{*}{$\begin{array}{c}\mathrm{M} \\
\text { Pol- } \\
\text { ished }\end{array}$} & \multirow[b]{2}{*}{$\begin{array}{l}\text { Lead } \\
\text { coated }\end{array}$} & \multirow[b]{2}{*}{$\begin{array}{l}\mathrm{K} \\
\text { Nor- } \\
\text { mal }\end{array}$} & \multirow[b]{2}{*}{$\underset{\text { Ground }}{\mathrm{D}}$} \\
\hline & $\begin{array}{c}\text { A } \\
\text { Nor- } \\
\text { mal }\end{array}$ & $\mid \begin{array}{c}\text { MC } \\
\text { Ma- } \\
\text { chined }\end{array}$ & $\begin{array}{c}\mathrm{C} \\
\text { Nor. } \\
\text { mal }\end{array}$ & $\mid \begin{array}{c}\text { MD } \\
\text { Ma- } \\
\text { chined }\end{array}$ & & & & & & \\
\hline \multirow{6}{*}{$\begin{array}{l}13 \\
24 \\
28 \\
29 \\
42 \\
45 \\
45 \\
\text { Ratio } 0 \\
\end{array}$} & $\begin{array}{r}17.8 \\
3.6 \\
20.4\end{array}$ & $\begin{array}{r}12.8 \\
3.2\end{array}$ & $\begin{array}{l}7.8 \\
3.8 \\
6.8\end{array}$ & $\begin{array}{l}9.1 \\
2.4\end{array}$ & $\begin{array}{r}16.7 \\
3.7\end{array}$ & 19.3 & 15.3 & $\begin{array}{l}6.5 \\
3.3 \\
9.1\end{array}$ & $\begin{array}{r}11.9 \\
4.7\end{array}$ & $\begin{array}{r}11.1 \\
3.8\end{array}$ \\
\hline & $\begin{array}{l}20.4 \\
11.4\end{array}$ & 5. & $\begin{array}{r}0.0 \\
10.7\end{array}$ & 8. & 7. & 10 & 9 & & 6.3 & $7 . \overline{3}$ \\
\hline & 17.9 & 15. & 7. & & & 8. & 10. & & & \\
\hline & 14.1 & 5.2 & 27.5 & 11. & 19 & 10. & 8.1 & 19.4 & 15.3 & 9.7 \\
\hline & 22.3 & & 14. 3 & 15. & & 16. 6 & 13. 0 & 10.1 & 12.9 & 18. 2 \\
\hline & & $5: 5$ & & $3: 6$ & $2: 5$ & & $4: 5$ & $4: 5$ & & $4: 6$ \\
\hline
\end{tabular}

PITTING FACTOR

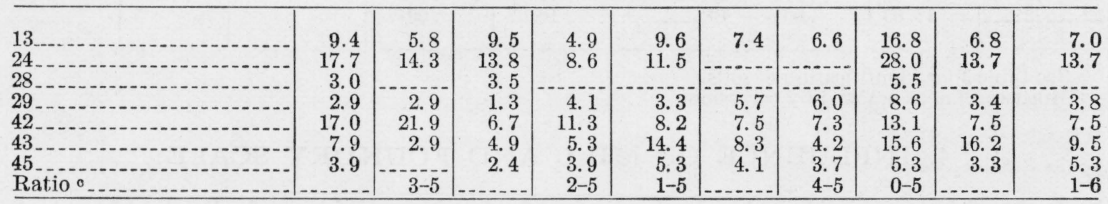

- Ratio of cases of superiority to total number of cases of comparison.

In the beginning of the discussion of this table it should be pointed out that the data are too few to justify positive conclusions as to the relative merits of the two types of pipe surfaces. Nevertheless, they are of considerable interest because they throw a little light on a question often discussed with no more than opinions as bases for discussion. Since the results in some soils show trends opposite to those in other soils and since the losses in some soils are so much greater than in others that averages would be meaningless, an attempt to show the trend of the data has been made by giving the ratio of the cases in which a material is superior to the total number of possible comparisons. Several comparisons can be made. Turning first to the data on machined and unmachined pit-cast iron, it appears that removing the outer skin or surface of this material tends to reduce both the loss of weight and the pit depths as well as to make the corrosion more uniform. This is a little surprising since the suggestion has been frequently advanced that the surface of cast-iron pipe has a siliceous scale which retards corrosion. However, since the sand mold in which the pipe was cast was coated with blacking, the metal absorbed little or no silica from the mold. Chemical analyses of cast surfaces showing high silicon content may be explained by the occasional imbedding of a particle of sand in the pipe surface.

A comparison of the unmachined and machined deLavaud cast iron shows the same tendency toward less corrosion of the machined specimens, though to a less marked extent. The semipolished steel appeared better with respect to loss of weight, pit depths, and pitting factor in three of the five soils. This result might be attributed to chance if it were not in accord with the results for other materials. The rough-ground wrought iron was superior to the ordinary material with respect to loss of weight in 5 out of 6 soils, though the differences were in all cases rather small. The ground wrought-iron specimens 
showed shallower maximum pits than the ordinary wrought iron in 4 of the 6 soils. The differences are small in 4 soils but large in 2 soils.

Considering the table as a whole, the character of the surface of the pipe with respect to the presence or absence of mill or foundry scale appears to have had an effect on the corrosion of the metals tested. This effect is small in comparison with the effects of soil characteristics on underground corrosion.

Table 13 indicates also that the addition of 1.5 percent of copper to steel did not increase its resistance to corrosion.

The specimens which were coated with lead lost less weight than did the uncoated steel specimens in all soils, and in 5 of the 6 soils the pit depths were less on the lead-coated pipes. In soil 43, a tidal marsh, the lead-coated specimens showed much deeper pits than the uncoated specimens. This is in agreement with other tests of the lead-coated specimens in this soil.

\section{EFFEC $T$ OF AREA AND DIAMETER OF SPECIMENS ON THE RATE OF PENETRATION}

Early in this soil-corrosion investigation ${ }^{9}$ it was observed that the average maximum pit for the $1 \frac{1}{2}$-inch specimens was less than the corresponding average maximum pit on the 3 -inch specimens of the same material, and to partially compensate for this the pit depths were weighted by averaging the deepest pits on the 2 specimens of $1 \frac{1}{2}$-inch material, the 2 deepest pits on each 2 - and 3-inch specimen, and the 4 deepest pits on each 6 -inch specimen. Since for one 6 -inch material (deLavaud cast iron) there were 2 specimens, the reported maximum pit depth for this material was actually the average of 8 pit depths, while the reported maximum pit depth for each material represented by $1 \frac{1}{2}$-inch specimens was the average of 2 pit depths. This procedure brought the results of observations on different sizes of the same material into closer agreement and has been followed in all subsequent reports.

In order to obtain additional data on the relation between the area of the specimens from which the maximum pit was chosen and the magnitude of the result obtained, specimens of each of two materials differing in size were buried in 13 soils in 1932. The dimensions and numbers of the specimens were so chosen that the total areas of each of the groups of specimens were approximately the same. Thus, in each soil there were 2 specimens of steel 2 inches in diameter and 10 inches long; 2 specimens each of steel and cast iron 3 inches in diameter and 6 inches long; 2 specimens of cast iron 1\%彳 inches nominal inside diameter and 13 inches long; and 1 specimen of 6 -inch cast iron, 6 inches long. The 4 deepest pits on each of the 6-inch specimens and the 2 deepest pits on each of the other specimens were measured. In table 14 the rates of penetration have been computed in three ways: (1) from the single deepest pit on the combined area for each material in a given soil; (2) from the average of the single deepest pits for each specimen of each material except the 6-inch cast iron for which there was only 1 specimen; and (3) the weighted average pit depth computed from the 4 deepest pits on the 6-inch specimens and the 2 deepest pits on each of the other sizes, i. e., the average of 4 pits in each case. This is the method used in reporting weighted maximum pit depths in this and earlier reports.

๑ Logan and Grodsky. Soil corrosion studies 1930. BS J. Research 7, 5 (19 ) RP379, 10c. 
TABLE 14.-Effect of the method of determining the value of the deepest pit

[Total pit depths on specimens buried for the purpose of studying the relation of pit depth to the area exposed. The total area is approximately the same for each diameter of specimen. There were two specimens of each size, except the 6 -inch cast iron]

\begin{tabular}{|c|c|c|c|c|c|c|c|c|c|c|c|c|c|c|c|}
\hline \multirow{3}{*}{ Soil a } & \multirow{3}{*}{$\begin{array}{c}\text { Dura- } \\
\text { tion } \\
\text { of } \\
\text { test }\end{array}$} & \multicolumn{6}{|c|}{ Steel pipe } & \multicolumn{8}{|c|}{ Cast-iron pipe } \\
\hline & & \multicolumn{3}{|c|}{2 inch $(N)^{b}$} & \multicolumn{3}{|c|}{3 inch $\left(M^{\prime}\right)$} & \multicolumn{3}{|c|}{$11 / 4$ inch $(G)$} & \multicolumn{2}{|c|}{3 inch $(M)$} & \multicolumn{3}{|c|}{6 inch $(L)$} \\
\hline & & $\begin{array}{l}\text { Sin- } \\
\text { gle } \\
\max \end{array}$ & $\begin{array}{l}\text { Avg } \\
\max \end{array}$ & $\begin{array}{l}\text { Wtd } \\
\max \end{array}$ & $\begin{array}{c}\text { Sin- } \\
\text { gle } \\
\max \end{array}$ & $\begin{array}{l}\text { Avg } \\
\max \end{array}$ & $\begin{array}{l}\text { Wtd } \\
\text { max }\end{array}$ & $\begin{array}{l}\text { Sin- } \\
\text { gle } \\
\max \end{array}$ & $\begin{array}{l}A v g \\
\max \end{array}$ & $\begin{array}{l}\text { Wtd } \\
\max \end{array}$ & $\begin{array}{l}\text { Sin- } \\
\text { gle } \\
\max \end{array}$ & $\begin{array}{l}\mathrm{Avg} \\
\max \end{array}$ & $\begin{array}{l}\text { Wtd } \\
\max \end{array}$ & $\begin{array}{c}\text { Sin- } \\
\text { gle } \\
\max \end{array}$ & $\begin{array}{l}\text { Wtd } \\
\max \end{array}$ \\
\hline - & $\begin{array}{l}\text { Years } \\
1.98 \\
1.96 \\
1.89 \\
1.99 \\
1.91\end{array}$ & $\begin{array}{r}101 \\
37 \\
42 \\
26 \\
34\end{array}$ & $\begin{array}{l}82 \\
37 \\
41 \\
20 \\
32\end{array}$ & $\begin{array}{l}80 \\
32 \\
39 \\
18 \\
30\end{array}$ & $\begin{array}{l}63 \\
56 \\
54 \\
65 \\
36\end{array}$ & $\begin{array}{l}49 \\
52 \\
48 \\
52 \\
30\end{array}$ & $\begin{array}{l}44 \\
50 \\
46 \\
48 \\
27\end{array}$ & $\begin{array}{r}138 \\
47 \\
50 \\
39 \\
53\end{array}$ & \begin{tabular}{|r|}
117 \\
42 \\
47 \\
36 \\
52 \\
\end{tabular} & $\begin{array}{r}102 \\
41 \\
45 \\
35 \\
46\end{array}$ & $\begin{array}{r}110 \\
54 \\
40 \\
55 \\
39\end{array}$ & $\begin{array}{l}78 \\
45 \\
36 \\
52 \\
38\end{array}$ & $\begin{array}{l}73 \\
39 \\
35 \\
49 \\
33\end{array}$ & $\begin{array}{l}87 \\
32 \\
57 \\
56 \\
49\end{array}$ & $\begin{array}{l}78 \\
27 \\
42 \\
38 \\
38\end{array}$ \\
\hline 62 & $\begin{array}{r}1.99 \\
1.92 \\
.95 \\
1.93 \\
2.04\end{array}$ & $\begin{array}{l}20 \\
55 \\
13 \\
68 \\
21\end{array}$ & $\begin{array}{l}18 \\
37 \\
10 \\
62 \\
15\end{array}$ & $\begin{array}{r}18 \\
36 \\
9 \\
55 \\
13\end{array}$ & $\begin{array}{l}31 \\
49 \\
30 \\
57 \\
41\end{array}$ & $\begin{array}{l}30 \\
34 \\
18 \\
50 \\
36\end{array}$ & $\begin{array}{l}27 \\
33 \\
17 \\
49 \\
34\end{array}$ & $\begin{array}{l}28 \\
58 \\
50 \\
67 \\
29\end{array}$ & $\begin{array}{l}27 \\
53 \\
43 \\
64 \\
24\end{array}$ & $\begin{array}{l}24 \\
51 \\
34 \\
64 \\
22\end{array}$ & $\begin{array}{r}45 \\
90 \\
5 \\
64 \\
50\end{array}$ & $\begin{array}{r}35 \\
82 \\
5 \\
47 \\
44\end{array}$ & $\begin{array}{r}34 \\
73 \\
5 \\
46 \\
42\end{array}$ & $\begin{array}{r}58 \\
90 \\
5 \\
90 \\
62\end{array}$ & $\begin{array}{r}54 \\
65 \\
5 \\
83 \\
60\end{array}$ \\
\hline 64 & $\begin{array}{l}1.91 \\
1.91 \\
1.92\end{array}$ & $\begin{array}{r}138 \\
43 \\
71\end{array}$ & $\begin{array}{r}130 \\
40 \\
66\end{array}$ & $\begin{array}{r}127 \\
39 \\
61\end{array}$ & $\begin{array}{r}134 \\
75 \\
120\end{array}$ & $\begin{array}{r}133 \\
66 \\
110\end{array}$ & $\begin{array}{r}129 \\
65 \\
106\end{array}$ & $\begin{array}{r}135 \\
53 \\
75\end{array}$ & $\begin{array}{r}123 \\
50 \\
60\end{array}$ & $\begin{array}{r}121 \\
49 \\
53\end{array}$ & $\begin{array}{r}215 \\
101 \\
74\end{array}$ & $\begin{array}{r}211 \\
93 \\
69\end{array}$ & $\begin{array}{r}208 \\
88 \\
66\end{array}$ & $\begin{array}{r}265 \\
145 \\
91\end{array}$ & $\begin{array}{r}225 \\
102 \\
75\end{array}$ \\
\hline $\begin{array}{l}\text { Average } \\
\text { Standard error. }\end{array}$ & $-\cdots$ & $\begin{array}{r}51.5 \\
9.9\end{array}$ & $\begin{array}{r}45.4 \\
9.2\end{array}$ & $\begin{array}{r}42.8 \\
9.0\end{array}$ & $\begin{array}{r}62.4 \\
8.8\end{array}$ & $\begin{array}{r}54.5 \\
9.0\end{array}$ & $\begin{array}{r}51.9 \\
8.9\end{array}$ & $\begin{array}{r}63.2 \\
9.7\end{array}$ & $\begin{array}{r}56.8 \\
8.4\end{array}$ & $\begin{array}{r}52.8 \\
8.0\end{array}$ & $\begin{array}{l}72.5 \\
14.2\end{array}$ & \begin{tabular}{|l|}
64.2 \\
13.9
\end{tabular} & \begin{tabular}{|l|}
60.8 \\
13.9
\end{tabular} & $\begin{array}{l}83.6 \\
17.8\end{array}$ & $\begin{array}{l}68.6 \\
14.9\end{array}$ \\
\hline
\end{tabular}

a See table 3 for identification of soils.

b See table 2 for identification of materials.

The corrosivities of the soils differ so greatly that the averages and standard errors recorded at the bottom of the table have little significance with respect to corrosion, but since all materials were exposed to the same soils the averages are of interest even though the size of the standard error indicates, from a statistical standpoint, that the relative magnitudes of the averages may be accidental. It will be noted, first, that for each type of specimen the single maximum pit depth is usually considerably greater than the average values. This is, of course, the result of unequal corrosion at different points on the pipe surfaces and at once raises a question as to how much greater the maximum pit would be if a length or a mile of pipe were taken as the unit for observation. At present this question cannot be answered, but there are definite indications that as the area under observation is increased the depth of the deepest pit also increases. This means that the values given for pit depths in the reports on underground corrosion by the Bureau of Standards should be increased if the maximum pit depth on an area greater than that of the unit used in the Bureau of Standards reports, i. e., that of a $1 \frac{11}{2}$-inch pipe, 5 inches long, is desired. This problem is being investigated further.

Turning to the question of the effect of using a number of pit depths proportional to the areas of the specimens for the purpose of comparing pit depths on specimens of different sizes, table 14 affords three opportunities for comparison. It will be seen that if either the average maximum or the weighted average maximum pit depths on the 2-inch specimens, $\mathrm{N}$, are compared with the corresponding pit depths on the 3 -inch specimens, $\mathbf{M}^{\prime}$, the average values for the 
specimens having the larger diameter are greater, although the areas of the two kinds of materials are approximately the same. Similarly, the averages for the 3 -inch cast iron are greater than for the $1 \frac{1}{2}$-inch cast iron, and the weighted maxima for the 3 -inch and 6 -inch castiron specimens show the same trend. The averages for the several materials are shown in figure 4.

While, as previously stated, the standard errors indicate that no positive differences between the averages have been demonstrated,

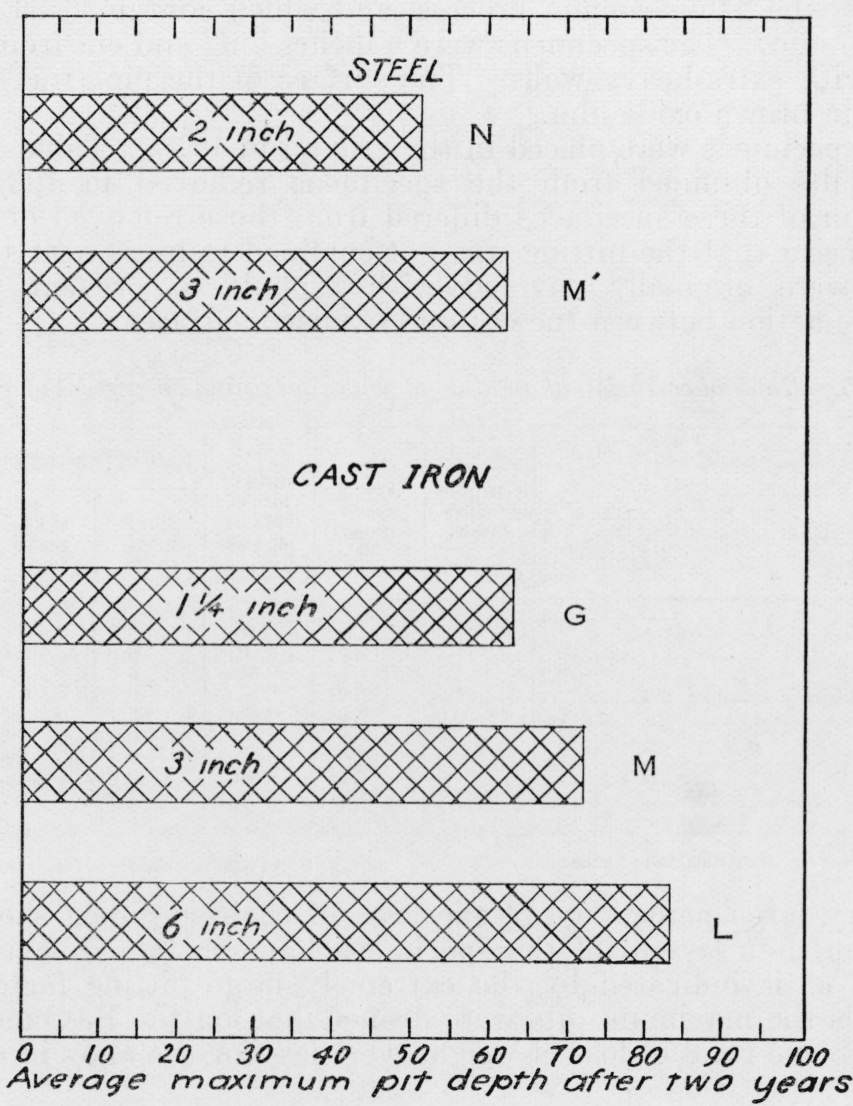

Figure 4.-Effect of pipe diameter on depth of maximum pit.

the fact that the trends in all cases are in the same direction carries at least a suggestion that the shape of the individual pipe sections, as well as the total area for which the maximum pit depth is computed, should be considered. The relation of the value of the maximum pit depth to the area and dimensions of the unit is important not only in the study of the Bureau of Standards data, but in the interpretation of inspection data which may be obtained for the purpose of determining the condition of operating pipe lines. 


\section{TESTS OF MATERIALS IN CORROSIVE SOILS}

\section{TUBES CONTAINING 26 PERCENT OF CHROMIUM}

The resistance of the alloys of iron and chromium to atmospheric corrosion has raised questions as to the desirability of adding small amounts of chromium to iron or steel in the manufacture of pipes for underground use. The first attempt by the Bureau of Standards to study this question was the burial of a few specimens of tubing made by the Mannesmann process, and which contained 26 percent of chromium. The specimens were 6 inches long and cut from 1-inch tubes with extra-heavy walls. The surface of the pipe was covered by a thin brown oxide film.

The specimens were placed in the ground in 1926 . Table 15 gives the results obtained from the specimens removed in 1934. The condition of these specimens differed from those removed on former occasions in that the pitting was not confined to areas near the ends which were originally covered with asphalt to prevent possible galvanic action between the cut and oxidized surfaces.

TABLE 15.-Rates of corrosion of an alloy of iron containing 26 percent of chromium

\begin{tabular}{|c|c|c|c|c|c|c|}
\hline \multirow[b]{2}{*}{ Soil a } & \multirow{2}{*}{$\begin{array}{l}\text { Number } \\
\text { of spec- } \\
\text { imens }\end{array}$} & \multirow{2}{*}{$\begin{array}{l}\text { Age of } \\
\text { speci- } \\
\text { mens }\end{array}$} & \multirow{2}{*}{$\begin{array}{l}\text { Rate of } \\
\text { loss of } \\
\text { weight } \\
\text { per year }\end{array}$} & \multicolumn{2}{|c|}{ Rate of penetration } & \multirow{2}{*}{$\begin{array}{l}\text { Average } \\
\text { pitting } \\
\text { factor }\end{array}$} \\
\hline & & & & $\begin{array}{l}\text { Single } \\
\text { maxi- } \\
\text { mum }\end{array}$ & $\begin{array}{l}\text { Avg. } \\
\text { maxi- } \\
\text { mum }\end{array}$ & \\
\hline $\begin{array}{l}13 \\
23 \\
28 \\
42\end{array}$ & $\begin{array}{l}3 \\
3 \\
3 \\
6 \\
3 \\
6 \\
6 \\
6\end{array}$ & $\begin{array}{r}\text { Years } \\
7.96 \\
7.96 \\
7.94 \\
7.96 \\
7.97 \\
7.97 \\
7.95 \\
7.95\end{array}$ & $\begin{array}{c}\mathrm{oz} / \mathrm{ft}^{2} \\
0.0054 \\
.0208 \\
.0067 \\
.0163 \\
.0352 \\
.0203 \\
.6747 \\
.0117\end{array}$ & $\begin{array}{r}0.0 \\
6.6 \\
0 \\
23.7 \\
10.2 \\
6.8 \\
30.0 \\
3.0\end{array}$ & $\begin{array}{r}0.0 \\
5.9 \\
0 \\
14.0 \\
8.2 \\
4.8 \\
24.5 \\
1.2\end{array}$ & $\begin{array}{r}1 \\
182 \\
1 \\
552 \\
149 \\
151 \\
23 \\
68\end{array}$ \\
\hline
\end{tabular}

a See table 3 for identification of soils.

A very large percentage of the area of each specimen showed no corrosion, but several of the specimens have sustained severe local pitting, as is indicated by the extremely large pitting factors. In two soils the maximum pits were deeper than on the Bessemer steel, although the rates of loss of weight were less for the alloy in all soils.

\section{PIPE BURIED IN 1932}

Table 16 shows the analyses of the ferrous materials buried in 1932 , as furnished by their producers. The dimensions of the specimens are given in table 2. 
TABLe 16.-Analyses a ferrous materials (in percent)

[See table 2 for dimensions of specimens]

\begin{tabular}{|c|c|c|c|c|c|c|c|c|c|c|c|}
\hline $\begin{array}{l}\text { Iden- } \\
\text { tifica- } \\
\text { tion } \\
\text { letter }\end{array}$ & Material & Gr & C. C. & T. C. & $\mathrm{Si}$ & Mn & S & $\mathrm{P}$ & $\mathrm{Cr}$ & $\mathrm{Ni}$ & $\mathrm{Cu}$ \\
\hline $\mathrm{A}$ & Puddled wrought iron b.......... & 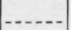 & & 0.026 & 0.100 & 0.029 & 0.018 & 0.160 & & & \\
\hline B & 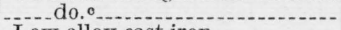 & & & .02 & 125 & .041 & .018 & .106 & & & \\
\hline $\mathrm{C}$ & Low alloy cast iron & 2.0 & 0.5 & 3.5 & 2.5 & .7 & .05 & .4 & 0.3 & 0.15 & --- \\
\hline $\mathrm{D}$ & Cu-Ni steel pipe & $-\ldots$ & .14 & .14 & .19 & .21 & -.... & $-\cdots$ & $--2--10$ & 2.47 & 1.08 \\
\hline $\mathrm{E}$ & High alloy cast iron...... & $\mid-\ldots$. & $\cdots-$ & 2.98 & 2.13 & 1.0 & $-\cdots$ & $-\cdots$ & 2.61 & 15.0 & 6.58 \\
\hline $\mathrm{F}$ & $\begin{array}{l}\text { Sand-coated cast iron } \\
\text { Rattled cast-iron pipe }\end{array}$ & 2.9 & .6 & 3.5 & 1.85 & .5 & .75 & .7 & & & \\
\hline $\mathrm{H}$ & Cu-Mo open-hearth iron pipe d. & & & .04 & .05 & .32 & .027 & .016 & & & .52 \\
\hline I & Special cast-iron pipe & 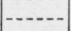 & - & 2. 53 & 1. 43 & .28 & .077 & .128 & 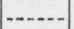 & 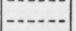 & .51 \\
\hline $\mathbf{J}$ & - do & - & - & 2.9 & 2.04 & .83 & .060 & .248 & $-\infty \ldots+-$ & $-\cdots---$ & .62 \\
\hline $\mathrm{K}$ & Cr-Ni alloy sheet & & .08 & .08 & .33 & .44 & .022 & .015 & 17.2 & 8.95 & \\
\hline $\begin{array}{l}\mathrm{L} \\
\mathrm{M}\end{array}$ & $\left.\begin{array}{l}\text { 6-in. cast-iron pipe } \\
\text { 3-in. cast-iron pipe }\end{array}\right\}$ avg.------- & 2.92 & .83 & 3. 75 & 1. 49 & .47 & .08 & .62 & & & .07 \\
\hline $\mathrm{N}$ & Low-carbon tube & & & .15 & & .49 & .030 & .013 & & & \\
\hline $\mathrm{P}$ & $5 \%$ Cr tube & & & .13 & & .46 & .025 & .012 & 5.05 & - & - \\
\hline$R$ & $\mathrm{Cr}-\mathrm{Ni}$ & . & & .05 & 28 & 46 & .011 & .015 & 17. 52 & 8.85 & \\
\hline$\stackrel{\mathrm{S}}{\mathrm{T}}$ & 1 alloy sheet & - & - & .07 & .48 & 9.44 & $-\cdots$ & ----- & 17.78 & & .74 \\
\hline$\stackrel{T}{\mathrm{U}}$ & heet & & & .06 & .40 & $\begin{array}{r}6.09 \\
38\end{array}$ & $---\overline{17}$ & & $\begin{array}{l}17.76 \\
11.95\end{array}$ & 3.83 & .95 \\
\hline V & - do do so & $-\cdots$ & & .070 & .34 & $\begin{array}{l}.38 \\
.36\end{array}$ & .015 & .014 & $\begin{array}{l}11.95 \\
17.08\end{array}$ & $\begin{array}{l}.482 \\
.092\end{array}$ & .021 \\
\hline W & Cr-1 & & & .093 & .42 & .36 & .017 & .008 & 18. 69 & 9.18 & .016 \\
\hline $\mathrm{X}$ & Cr alloy tube & & & .12 & .277 & .42 & .017 & .016 & 17. 72 & .287 & \\
\hline $\mathrm{Y}$ & Cr-Ni alloy sheet & & & .144 & .59 & 1.80 & .011 & .015 & 22.68 & 12.94 & .021 \\
\hline
\end{tabular}

a These analyses were furnished by the manufacturers of the materials. In some cases they may represent the average analyses of the materials represented rather than of the specimens submitted for test.

b Oxide and slag, $2.560 \%$.

- Oxide and slag, $2.681 \%$

d Molybdenum, $0.15 \%$.

Included in the test are several sets of specimens placed there to serve as reference specimens or to answer some question not dealing directly with the corrosion-resisting properties of the material. The test differs from the earlier ones in that it was confined to corrosive soils. The results will, therefore, not be indicative of the performance of the materials under average soil conditions. The test differs from the earlier ones also in that the pipe specimens were laid on their sides, had the ends closed to prevent internal corrosion, and were so chosen that on each specimen approximately the same area was exposed to the soil.

The specimens of stainless-steel sheet metal were placed on edge in order that both surfaces should be exposed to the same condition.

Two specimens of each kind of pipe, except two, were removed from each of 14 soils in 1934 . The average rates of loss of weight for these specimens are recorded in table 17 . While in a large majority of cases the two specimens of the same material in the same soil agree quite closely with respect to loss of weight, there are a few cases in which one specimen lost approximately twice that of its mate. 
TABLE 17.-Rates of loss of weight of ferrous pipe buried in 1932

[Ounces per square foot per year]

\begin{tabular}{|c|c|c|c|c|c|c|c|c|c|c|c|c|c|c|}
\hline Soil a & 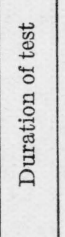 & 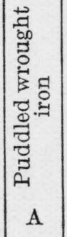 & 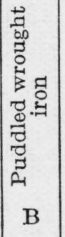 & 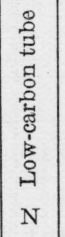 & $\begin{array}{l}00 \\
Z \\
2 \\
01 \\
50 \\
10 \\
\mathrm{P}\end{array}$ & 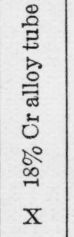 & 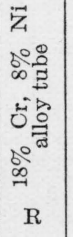 & 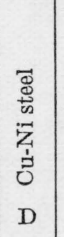 & 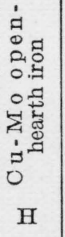 & 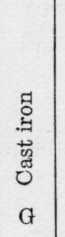 & 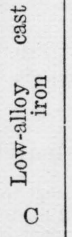 & 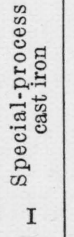 & 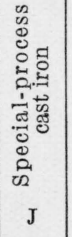 & 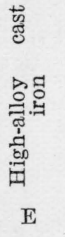 \\
\hline 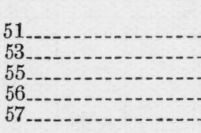 & \begin{tabular}{|l|}
$\mathrm{yr}$ \\
1.98 \\
1.96 \\
1.89 \\
1.99 \\
1.91
\end{tabular} & $\begin{array}{l}5.93 \\
1.77 \\
1.51 \\
1.76 \\
1.82\end{array}$ & $\begin{array}{l}4.14 \\
1.75 \\
1.52 \\
2.22 \\
1.65\end{array}$ & $\begin{array}{l}3.75 \\
1.37 \\
1.28 \\
2.03 \\
2.33\end{array}$ & $\begin{array}{r}3.23 \\
.69 \\
.61 \\
1.26 \\
2.31\end{array}$ & & 0.000 & $\begin{array}{r}2.39 \\
1.10 \\
.88 \\
1.67 \\
1.49\end{array}$ & $\begin{array}{l}3.12 \\
1.41 \\
1.04 \\
1.17 \\
2.72\end{array}$ & $\begin{array}{l}5.60 \\
2.40 \\
1.42 \\
4.75 \\
1.74\end{array}$ & $\begin{array}{l}7.62 \\
1.97 \\
1.81 \\
3.61 \\
2.25\end{array}$ & $\begin{array}{l}7.50 \\
1.55 \\
1.48 \\
2.58 \\
2.75\end{array}$ & $\begin{array}{l}7.43 \\
1.57 \\
2.07 \\
2.56 \\
2.96\end{array}$ & $\begin{array}{r}2.31 \\
.61 \\
.40 \\
1.67 \\
.18\end{array}$ \\
\hline $\begin{array}{l}62 .- \\
63 .\end{array}$ & $\begin{array}{r}1.99 \\
1.92 \\
.95 \\
1.93 \\
2.04\end{array}$ & $\begin{array}{l}1.76 \\
2.96 \\
1.38 \\
1.56 \\
1.48\end{array}$ & $\begin{array}{l}1.60 \\
2.62 \\
1.29 \\
2.09 \\
1.30\end{array}$ & $\begin{array}{r}1.85 \\
3.24 \\
.86 \\
2.12 \\
1.88\end{array}$ & $\begin{array}{r}.91 \\
2.24 \\
.82 \\
1.25 \\
.65\end{array}$ & $\begin{array}{l}.002 \\
.001 \\
.017\end{array}$ & \begin{tabular}{r}
.001 \\
\hdashline .000 \\
.012
\end{tabular} & $\begin{array}{r}1.77 \\
2.53 \\
1.25 \\
1.41 \\
.77\end{array}$ & $\begin{array}{r}1.45 \\
2.54 \\
.98 \\
1.92 \\
1.22\end{array}$ & $\begin{array}{l}2.92 \\
5.50 \\
1.12 \\
3.48 \\
1.87\end{array}$ & $\begin{array}{l}4.54 \\
4.69 \\
1.29 \\
3.30 \\
1.52\end{array}$ & $\begin{array}{r}2.32 \\
5.12 \\
.99 \\
3.39 \\
1.38\end{array}$ & $\begin{array}{l}1.85 \\
4.07 \\
1.07 \\
3.51 \\
2.25\end{array}$ & $\begin{array}{r}.42 \\
2.17 \\
.28 \\
.86 \\
.28\end{array}$ \\
\hline 656 & $\begin{array}{l}1.91 \\
1.91 \\
1.92 \\
2.02\end{array}$ & $\begin{array}{l}5.96 \\
4.16 \\
4.47 \\
4.28\end{array}$ & $\begin{array}{l}6.94 \\
3.22 \\
4.06 \\
5.67\end{array}$ & $\begin{array}{r}6.62 \\
3.87 \\
4.02 \\
10.65\end{array}$ & $\begin{array}{l}7.32 \\
3.78 \\
4.03 \\
3.68\end{array}$ & \begin{tabular}{c}
.264 \\
\hdashline .003 \\
\end{tabular} & $\begin{array}{r}.001 \\
.000 \\
\end{array}$ & \begin{tabular}{|l|}
3.40 \\
2.61 \\
2.66 \\
8.16
\end{tabular} & $\begin{array}{l}8.44 \\
3.92 \\
4.57 \\
3.84\end{array}$ & $\begin{array}{r}6.59 \\
5.40 \\
3.13 \\
13.25\end{array}$ & $\begin{array}{r}7.52 \\
6.76 \\
4.31 \\
10.63\end{array}$ & $\begin{array}{r}8.09 \\
6.24 \\
2.64 \\
15.00 \\
\end{array}$ & $\begin{array}{r}8.34 \\
5.76 \\
3.14 \\
12.18\end{array}$ & $\begin{array}{r}2.32 \\
.80 \\
1.60 \\
8.74\end{array}$ \\
\hline $\begin{array}{l}\text { Average } \\
\text { Avg } 67 \text { omi }\end{array}$ & & $\begin{array}{l}2.91 \\
2.77\end{array}$ & $\begin{array}{l}2.86 \\
2.65\end{array}$ & $\begin{array}{l}3.27 \\
2.71\end{array}$ & $\begin{array}{l}2.34 \\
2.24\end{array}$ & .048 & $\begin{array}{r}.002 \\
-. .-\end{array}$ & \begin{tabular}{|l|}
2.29 \\
1.84
\end{tabular} & $\begin{array}{l}2.74 \\
2.65\end{array}$ & \begin{tabular}{|l|}
4.23 \\
3.53
\end{tabular} & $\begin{array}{l}4.42 \\
3.94\end{array}$ & $\begin{array}{l}4.36 \\
3.54\end{array}$ & $\begin{array}{l}\text { 4. } 20 \\
3.58\end{array}$ & $\begin{array}{l}1.62 \\
1.07\end{array}$ \\
\hline
\end{tabular}

a See table 3 for names of soils.

So many figures are presented in the table that it is difficult for a reader to grasp the significance of the individual rates. For this reason the average rate has been computed for each material in all soils, although it is recognized that the dispersion of the values going to make up the average is so great that the average rate has little practical significance, and that the relative merits of the materials might be changed if the tests were extended to other soils. Thus for most of the materials the average rate of loss of weight is markedly affected by the specimens that were removed from soil 67 . For example, if the data for this soil were omitted the average rate of loss for Bessemer steel would be reduced from $3.3 \mathrm{oz} / \mathrm{ft}^{2} / \mathrm{yr}$ to $2.7 \mathrm{oz} / \mathrm{ft}^{2} / \mathrm{yr}$, while for copper-molybdenum-iron alloy the change is much less, $i$. e., from $2.74 \mathrm{oz} / \mathrm{ft}^{2} / \mathrm{yr}$ to $2.65 \mathrm{oz} / \mathrm{ft}^{2} / \mathrm{yr}$. It should be remembered also that when the specimens have been exposed for a longer time their rates of corrosion may be relatively different.

Table 18 shows the rates of maximum penetration for the ferrous pipe materials buried in 1932. The average maximum rates of penetration are shown graphically in figures 5 and 6 . In the latter figure the rates are for only the soils to which all the materials in the figure were exposed.

The standard error which is given for the averages of all specimens removed from each soil is so large that small differences in the averages for 10 materials are not significant. Thus, the table indicates that the 2 sets of wrought-iron specimens are so nearly alike that any differences between the two materials cannot be determined from the data. Likewise, the addition of 5 percent of chromium to low-carbon steel did not produce a positive difference between the two materials. 
TABLE 18.-Rates of maximum penetration of ferrous pipe buried in 1932

[A verage maximum rate of penetration, in mils per year]

\begin{tabular}{|c|c|c|c|c|c|c|c|c|c|c|c|c|c|c|c|}
\hline Soil a & 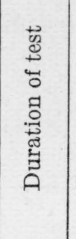 & 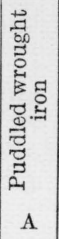 & 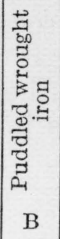 & 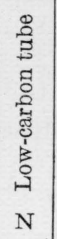 & $\begin{array}{l}8 \\
\frac{8}{7} \\
+3 \\
04 \\
0 \\
00 \\
10 \\
P \\
P\end{array}$ & 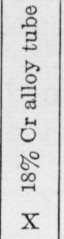 & 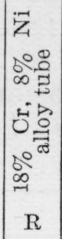 & $\begin{array}{l}\vec{\Phi} \\
\stackrel{\$}{0} \\
\vec{Z} \\
\dot{Z} \\
\dot{3} \\
0 \\
D\end{array}$ & 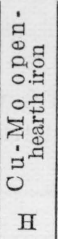 & 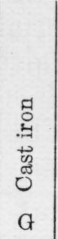 & 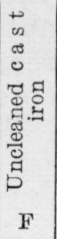 & 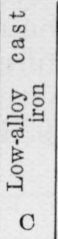 & 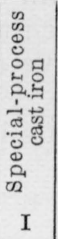 & 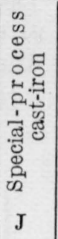 & 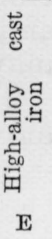 \\
\hline $57 \ldots$ & $\begin{array}{r}\text { Years } \\
1.98 \\
1.96 \\
1.89 \\
1.99 \\
1.91\end{array}$ & $\begin{array}{r}25.2 \\
17.3 \\
21.4 \\
11.1 \\
9.2\end{array}$ & $\begin{array}{l}30.0 \\
15.3 \\
22.5 \\
12.3 \\
10.5\end{array}$ & $\begin{array}{r}41.4 \\
18.9 \\
21.7 \\
9.8 \\
16.8\end{array}$ & $\begin{array}{l}34.8 \\
23.5 \\
22.5 \\
29.1 \\
13.6\end{array}$ & 8.1 & & $\begin{array}{l}34.1 \\
11.7 \\
17.2 \\
10.1 \\
16.2\end{array}$ & $\begin{array}{l}39.7 \\
27.8 \\
31.7 \\
10.3 \\
26.2\end{array}$ & $\begin{array}{l}59.3 \\
21.4 \\
25.1 \\
18.3 \\
27.2\end{array}$ & $\begin{array}{l}45.4 \\
24.2 \\
25.1 \\
20.6 \\
25.4\end{array}$ & $\begin{array}{l}56.9 \\
19.9 \\
13.8 \\
16.3 \\
42.7\end{array}$ & $\begin{array}{l}51.5 \\
15.6 \\
15.1 \\
10.8 \\
21.7\end{array}$ & $\begin{array}{l}53.3 \\
27.6 \\
19.0 \\
14.8 \\
25.7\end{array}$ & $\begin{array}{l}15.4 \\
15.1 \\
15.9 \\
21.4 \\
13.6\end{array}$ \\
\hline $\begin{array}{l}58 \\
60 \\
62 \\
63 \\
64\end{array}$ & $\begin{array}{r}1.99 \\
1.92 \\
.95 \\
1.93 \\
2.04 \\
1.91\end{array}$ & $\begin{array}{l}10.1 \\
12.8 \\
17.9 \\
25.4 \\
13.7 \\
53.1\end{array}$ & \begin{tabular}{r|}
8.8 \\
12.2 \\
10.5 \\
36.0 \\
8.1 \\
61.5
\end{tabular} & \begin{tabular}{r|}
9.0 \\
19.3 \\
11.1 \\
32.1 \\
7.4 \\
68.3
\end{tabular} & $\begin{array}{l}17.8 \\
17.2 \\
10.5 \\
26.7 \\
21.1 \\
65.2\end{array}$ & $\begin{array}{r}5.0 \\
-6.2 \\
62.0 \\
80.6\end{array}$ & $\begin{array}{r}6.3 \\
-6.0 \\
20.8 \\
4.2\end{array}$ & $\begin{array}{l}11.6 \\
14.3 \\
12.1 \\
21.8 \\
11.8 \\
51.0\end{array}$ & $\begin{array}{l}10.6 \\
14.1 \\
15.3 \\
37.0 \\
14.5 \\
80.1\end{array}$ & $\begin{array}{l}13.3 \\
27.3 \\
45.3 \\
33.4 \\
11.5 \\
64.7\end{array}$ & $\begin{array}{l}17.3 \\
25.5 \\
25.8 \\
36.0 \\
18.4 \\
68.6\end{array}$ & $\begin{array}{r}22.4 \\
18.0 \\
15.8 \\
41.7 \\
4.7 \\
74.6\end{array}$ & $\begin{array}{l}20.6 \\
19.5 \\
31.6 \\
52.1 \\
10.0 \\
70.9\end{array}$ & $\begin{array}{l}14.1 \\
19.5 \\
27.9 \\
35.2 \\
25.0 \\
62.6\end{array}$ & $\begin{array}{l}25.1 \\
12.5 \\
37.9 \\
22.3 \\
11.0 \\
14.4\end{array}$ \\
\hline 66 & $\begin{array}{l}1.91 \\
1.92 \\
2.02\end{array}$ & $\begin{array}{l}28.3 \\
45.6 \\
49.7\end{array}$ & $\begin{array}{l}34.3 \\
42.4 \\
48.8\end{array}$ & $\begin{array}{l}20.7 \\
34.4 \\
76.2\end{array}$ & $\begin{array}{l}35.6 \\
44.5 \\
31.9\end{array}$ & 8.9 & 3.2 & $\begin{array}{l}21.5 \\
29.9 \\
50.0\end{array}$ & $\begin{array}{l}48.9 \\
57.8 \\
32.2\end{array}$ & $\begin{array}{l}26.2 \\
31.2 \\
79.0\end{array}$ & $\begin{array}{l}24.3 \\
29.2 \\
63.9\end{array}$ & $\begin{array}{l}30.6 \\
35.2 \\
58.9\end{array}$ & $\begin{array}{l}29.3 \\
29.7 \\
63.6\end{array}$ & $\begin{array}{l}30.1 \\
27.9 \\
53.2\end{array}$ & $\begin{array}{l}13.4 \\
13.8 \\
46.3\end{array}$ \\
\hline $\begin{array}{l}\text { A verage } \\
\text { Standard error... }\end{array}$ & & $\begin{array}{r}24.3 \\
4.0\end{array}$ & $\begin{array}{r}25.2 \\
4.6\end{array}$ & $\begin{array}{r}27.7 \\
5.7\end{array}$ & $\begin{array}{r}28.1 \\
3.8\end{array}$ & & & $\begin{array}{r}22.4 \\
3.7\end{array}$ & $\begin{array}{r}31.9 \\
5.4\end{array}$ & $\begin{array}{r}34.5 \\
5.4\end{array}$ & $\begin{array}{r}32.1 \\
4.3\end{array}$ & $\begin{array}{r}32.3 \\
5.5\end{array}$ & $\begin{array}{r}31.6 \\
5.3\end{array}$ & $\begin{array}{r}31.1 \\
4.0\end{array}$ & $\begin{array}{r}19.9 \\
2.8\end{array}$ \\
\hline
\end{tabular}

a See table 3 for names of soils.

Desire for economy prevented the burial of the two materials containing 18 percent of chromium in all of the soils and for this reason the averages for these materials cannot be compared with those for other materials. Comparing the low-carbon steel without chromium with a material which is similar except for the addition of 18 percent of chromium, it appears that the latter material is probably somewhat better in two of the soils, much better in one, and much worse in the fifth. It is not possible to determine whether or not these differences are significant. The addition of 8 percent of nickel to the ironchromium alloy seems to result in a definite improvement in the material with respect to loss of weight and rate of maximum penetration. The beneficial effect of the nickel is also indicated by the data for copper-nickel steel and high alloy cast iron.

With the exception of the last-named material all of the cast materials seem to corrode at approximately the same rates. While the data in the table taken at their face values indicate that some materials are relatively more suitable for some soils than for others the number of observations is too small and the time of exposure is too short to justify more than very tentative deductions as to the relative merits of the materials.

\section{SHEET METAL CONTAINING CHROMIUM}

Several varieties of this class of alloys have been included at 7 of the sites for testing corrosion-resistant materials. If the chemical constituents of the materials were the only factors affecting their corrosion a correlation of the analyses of the materials with their rates of corrosion might lead to the development of a more corrosion-resistant 
material. It is possible, however, that the heat treatment of the material and the roughness of its surface have important effects. Unfortunately, the surface finish of the specimens differed considerably and since the materials came from three sources the heat treatments may have differed also.

Table 19 records the corrosion data for the sheet specimens removed in 1934. The number in parentheses immediately under the

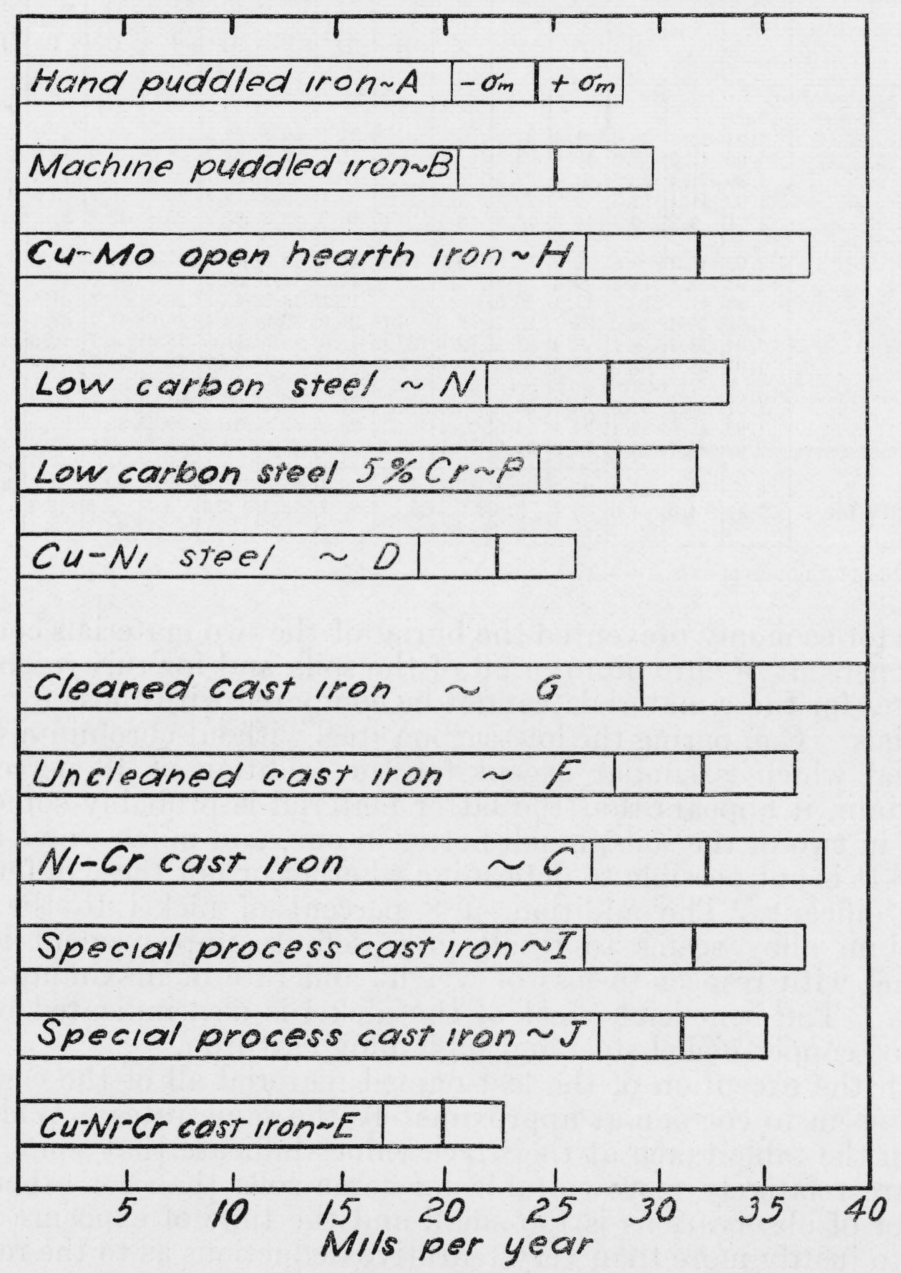

FIGURE 5.-Rates of penetration of several ferrous materials exposed for two years to fourteen corrosive soils.

letter designating the material indicates the number of specimens removed from any one soil. The specimens were so thin that in 3 soils most of them were punctured. For this reason the data on rates of penetration are not as useful as similar data on pipes. Table 20 repeats part of the data in table 19 and gives the standard error for the repeated data. From the standard error the dependability of the data may be judged. Where the losses are very small it is more diffi- 
cult to determine the average loss with precision but this only accounts, in part, for the standard error which, in one case, is nearly as large as the rate of loss of weight. An examination of the specimens would show that while in most cases most of the specimens of any material in one soil behaved similarly, occasionally an exceptionally good or bad specimen is to be found. While the pitting factor has not been computed it can safely be said to be very large in all cases.

The rates of loss are so different for the same material in different soils that in most cases the rate for one of the soils would almost determine the average for all of the soils, and on this account the rates of loss have not been averaged.

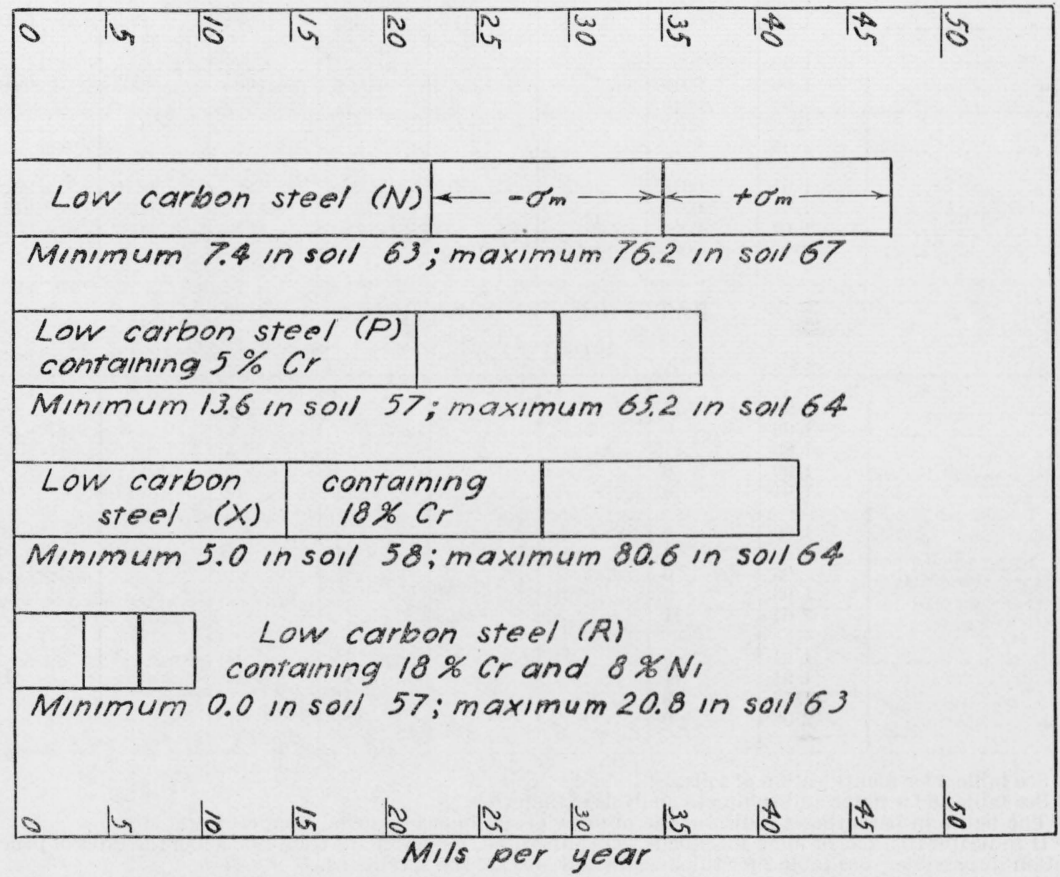

FigURE 6.-Rates of penetration of alloy steels exposed for two years to six soils.

For all soils concerned except two, the specimens containing the least chromium corroded the most. Soil 64 was the most destructive with respect to the materials containing very little nickel, while soil 65 was more corrosive than soil 64 with respect to all but one class of the specimens containing considerable amounts of nickel. This relation is not supported by the data for specimen $K$ (table 19 ), but since the 2 specimens of this material in either of the above soils differed very greatly in their losses the data for material $K$ are not very helpful. It is rather surprising that the material containing the most chromium and nickel corroded distinctly more than one of the other materials in every soil to which it was exposed. 
TABLE 19.-Average rates of loss of weight and maximum penetration of iron-chromium alloy sheets

RATES OF LOSS OF WEIGHT

[Ounces per square foot per year]

\begin{tabular}{|c|c|c|c|c|c|c|c|c|}
\hline Soil a & Exposure & $\begin{array}{c}\mathrm{K} \text { b } \\
(2) \circ \\
17 \% \mathrm{Cr} \\
9 \% \mathrm{Ni} \\
0.4 \% \mathrm{Mn}\end{array}$ & $\begin{array}{c}\mathrm{S} \\
(2) \\
18 \% \mathrm{Cr} \\
0 \% \mathrm{Ni} \\
9 \% \mathrm{Mn}\end{array}$ & $\begin{array}{c}\mathrm{T} \\
(1) \\
18 \% \mathrm{Cr} \\
4 \% \mathrm{Ni} \\
6 \% \mathrm{Mn}\end{array}$ & $\begin{array}{c}\mathrm{U} \\
(5) \\
12 \% \mathrm{Cr} \\
0.5 \% \mathrm{Ni} \\
0.4 \% \mathrm{Mn}\end{array}$ & $\begin{array}{c}\mathrm{V} \\
(5) \\
17 \% \mathrm{Cr} \\
0.1 \% \mathrm{Ni} \\
0.40 \% \mathrm{Mn}\end{array}$ & $\begin{array}{c}\text { W } \\
(5) \\
19 \% \mathrm{Cr} \\
9 \% \mathrm{Ni} \\
0.4 \% \mathrm{Mn}\end{array}$ & $\begin{array}{c}\mathrm{Y} \\
(5) \\
23 \% \mathrm{Cr} \\
13 \% \mathrm{Ni} \\
1.8 \% \mathrm{Mn}\end{array}$ \\
\hline $\begin{array}{l}51 \\
53 \\
55 \\
57\end{array}$ & $\begin{array}{l}\text { Years } \\
1.98 \\
1.96 \\
1.89 \\
1.99 \\
1.91\end{array}$ & $\begin{array}{r}0.0046 \\
.0022 \\
.0007 \\
.0003\end{array}$ & 0.0013 & $\begin{array}{r}0.0046 \\
.0022 \\
.0007 \\
.011\end{array}$ & 0.0004 & $\begin{array}{c}0.0018 \\
.027\end{array}$ & $\begin{array}{r}0.0002 \\
.0003\end{array}$ & 0.0011 \\
\hline $\begin{array}{l}58 \\
60 \\
61 \\
63\end{array}$ & $\begin{array}{r}1.99 \\
1.92 \\
.95 \\
1.93 \\
2.04\end{array}$ & $\begin{array}{l}.0007 \\
.0015 \\
.0010 \\
.0007 \\
.017\end{array}$ & 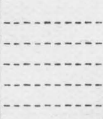 & & 0006 & .0004 & .0003 & .0015 \\
\hline 6464 & $\begin{array}{l}1.91 \\
1.91 \\
1.92 \\
2.02\end{array}$ & $\begin{array}{l}.0076 \\
.0026 \\
.0004 \\
.0005\end{array}$ & .048 & .057 & $\begin{array}{l}.35 \\
.068 \\
.039\end{array}$ & $\begin{array}{l}.28 \\
.065 \\
.028\end{array}$ & $\begin{array}{l}.0010 \\
.0055 \\
.0002 \\
. .--\end{array}$ & $\begin{array}{l}.0015 \\
.019 \\
.0015 \\
.0\end{array}$ \\
\hline
\end{tabular}

RATES OF PENETRATION

[Mils per year]

\begin{tabular}{|c|c|c|c|c|c|c|c|c|}
\hline 51 & 1. 98 & d $\underset{0}{\mathrm{H}}$ & $-\cdots$ & & - & & & \\
\hline 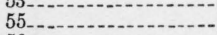 & 1. 89 & & $-\cdots$ & - & -+ & 3 & & 3 \\
\hline 56 & $\begin{array}{l}1.99 \\
1.91\end{array}$ & $\begin{array}{l}0 \\
0\end{array}$ & - & h-n & H & 14 & 17 & 0 \\
\hline 58 & 1. 99 & 0 & & & & & & \\
\hline $60 \ldots$ & 1. 92 & 0 & $-\cdots$ & & 1 & 0 & 1 & 1 \\
\hline 61 & .95 & 0 & $-\cdots$ & $-\cdots$ & - & & 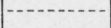 & \\
\hline 63 & $\begin{array}{l}1.93 \\
2.04\end{array}$ & H & 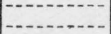 & $-\cdots$ & $-\cdots$ & $-\cdots$ & $-\cdots$ & (n) \\
\hline 64 & 1. 91 & 9 & $\mathrm{H}$ & $\mathrm{H}$ & $\mathrm{H}$ & $\mathrm{H}$ & 4 & \\
\hline $65 \ldots$ & 1.91 & $\mathrm{H}$ & & & $\mathrm{H}$ & $\mathrm{H}$ & $\mathrm{H}$ & H \\
\hline 66 & 1.92 & 0 & $\ldots$ & $\ldots$ & $\mathrm{H}$ & 0 & 5 & 3 \\
\hline 67 & 2.02 & 0 & 2 & 0 & & & & \\
\hline
\end{tabular}

a See table 3 for identification of soils.

b See table 16 for name and complete analysis of materials.

c The figure in parentheses indicates the number of specimens removed from each test site.

$\mathrm{d} \mathrm{H}$ indicates that one or more specimens were punctured, rendering the computation of the rates of penetration impossible. See table 2 for thicknesses and areas of the specimens.

TABLE 20.-Rates of loss of weight for four varieties of iron-chromium alloy sheets (in ounces per square foot per year)

[Age approximately 2 years]

\begin{tabular}{|c|c|c|c|c|c|c|c|c|}
\hline \multirow{2}{*}{ Soil a } & \multicolumn{2}{|c|}{$\begin{array}{c}\text { Ub } \\
\text { Cr } 12 \%, \mathrm{Ni} 5 \%, \\
\text { Mn } 4 \%\end{array}$} & \multicolumn{2}{|c|}{$\begin{array}{c}\mathrm{V} \\
\text { Cr } 17 \%, \mathrm{Ni} 1 \%, \\
\operatorname{Mn} 4 \%\end{array}$} & \multicolumn{2}{|c|}{$\begin{array}{c}\text { W } \\
\text { Cr } 19 \%, \mathrm{Ni} 9 \%, \\
\text { Mn } 4 \%\end{array}$} & \multicolumn{2}{|c|}{$\begin{array}{c}\mathrm{Y} \\
\mathrm{Cr} 23 \%, \mathrm{Ni} 13 \% \\
\mathrm{Mn} 1.8 \%\end{array}$} \\
\hline & $\begin{array}{c}\text { Average } \\
\text { loss }\end{array}$ & $\begin{array}{c}\text { Standard } \\
\text { error }\end{array}$ & $\begin{array}{l}\text { Average } \\
\text { loss }\end{array}$ & $\begin{array}{c}\text { Standard } \\
\text { error }\end{array}$ & $\begin{array}{c}\text { A verage } \\
\text { loss }\end{array}$ & $\begin{array}{c}\text { Standard } \\
\text { error }\end{array}$ & $\begin{array}{l}\text { Average } \\
\text { loss }\end{array}$ & $\begin{array}{c}\text { Standard } \\
\text { error }\end{array}$ \\
\hline $\begin{array}{l}55 \\
64 \\
64 \\
66\end{array}$ & $\begin{array}{l}0.0004 \\
.052 \\
.0006 \\
.35 \\
.068 \\
.039\end{array}$ & $\begin{array}{l}0.00018 \\
.023 \\
.00009 \\
.03012 \\
.00065 \\
.0089\end{array}$ & $\begin{array}{l}0.0018 \\
.027 \\
.0004 \\
.28 \\
.065 \\
.028\end{array}$ & $\begin{array}{l}0.0010 \\
.0060 \\
.0002 \\
.029 \\
.0053 \\
.011\end{array}$ & $\begin{array}{r}0.0002 \\
.0003 \\
.0003 \\
.0010 \\
.0060 \\
.0002\end{array}$ & $\begin{array}{l}0.0001 \\
.0001 \\
.0001 \\
.0004 \\
.0046 \\
.00003\end{array}$ & $\begin{array}{l}0.0011 \\
.0017 \\
.0015 \\
.0015 \\
.019 \\
.0015\end{array}$ & $\begin{array}{r}0.0001 \\
.0004 \\
.0002 \\
.0007 \\
.0119 \\
.0003\end{array}$ \\
\hline
\end{tabular}

a See table 3 for identification of soils.

bee table 16 for complete anaiyses of materials. 


\section{SUMMARY}

Since, in certain localities at least, the field work of the original soil-corrosion investigation has been completed, it may be well to include in the summary of the work on the 1934 specimens presented in this report, a statement of all of the more important facts which the entire investigation has brought out. Some of these statements can only be confirmed by references to the earlier soil-corrosion reports referred to in this paper.

1. Serious corrosion of underground pipes frequently occurs in the absence of stray currents from electrical generating stations. Electrical currents which did not originate in power houses have been observed on many pipe lines.

2. Soil conditions have a greater effect than the type of pipe material in determining the rate of corrosion of ferrous pipes in the absence of stray electric currents.

3 . There is a relation between the average rate of corrosion of iron in soil and the soil type, but the dispersion of the data which make up the average rate is very large. This is because conditions within a soil type are not always the same. It follows that while a soil type may be designated as noncorrosive, a pipe in that soil may develop a single leak within a few years, but many leaks are not to be expected.

4. Generally speaking, the larger the area from which the deepest pit is chosen the deeper the pit. This fact has an important bearing on the determination of the condition of a pipe line by means of local inspections. In order to make pit-depth measurements comparable, similar methods of inspecting pipes must be used.

5 . The relation of the pit depth to the duration of the exposure depends on soil conditions. In some types of soil the penetration is nearly proportional to the time of exposure, but in other soils pit depths deepen very slowly after soil conditions have become stable and corrosion products have formed on the surface of the pipe. This fact has an important bearing on the estimation of pipe life. In general, the life of a pipe should not be estimated solely from its age and the depth of the deepest pit because in most soils the rate of corrosion decreases with the time of exposure.

6 . The distribution of corrosion usually tends to become more uniform as the age of the pipe increases.

7. Under similar soil conditions the wrought iron and steel specimens corroded at approximately the same rates during the first 12 years of exposure. In many of the soils under tests, especially those in the arid regions containing large amounts of soluble salts, the rate of corrosion of cast iron is somewhat greater than that of steel. From a practical standpoint the thickness of the material and the nature of the corrosion products should also be taken into account in determining the material most suitable for some soil condition.

8. The addition of copper alone to steel does not increase its resistance to the action of most soils.

9. The rate of corrosion of pipe underground is not greatly affected by the removal of mill or foundry scale, but the available data seem to indicate a slight reduction in loss and penetration when the scale is removed. 
10. No material has been found which will withstand corrosion under all soil conditions.

The following tentative deductions are based on a relatively few specimens exposed to 14 corrosive soils for approximately 2 years.

1. The addition of chromium to steel reduces the rate of loss of weight but does not prevent serious localized pitting in all soils. The pitting seems to be worst in soils containing chlorides.

2. The addition of nickel to iron-chromium alloys seems to improve their resistance to underground corrosion.

3. An alloy containing 18 percent of chromium and 8 percent of nickel corroded less than an alloy containing more of these elements.

The work of cleaning the specimens upon which this report is based was undertaken at a time when the number of men available for the work was less than half that formerly available, although the number of specimens to be handled had been approximately doubled. Moreover, with the exception of the author, no one was left who was entirely familiar with the specimens or the processes involved in cleaning them. The work was undertaken by Robert Hobbs with the assistance of one laborer. A little later a group of pipe manufacturers contributed funds for the employment of labor for cleaning the specimens. This was supplemented by the part-time assistance of a man from Federal relief rolls. A large part of the computations have been made and checked by relief workers.

Near the close of the work, after all of the above-named assistance had been lost, the work was finished through the efforts of A. L. Lewis and L. M. Martin. To all of those mentioned the author is indebted for the assistance they rendered.

Washington, February 27, 1936. 